\title{
Identifying archaeological evidence of past earthquakes in a contemporary disaster scenario: case studies of damage, resilience and risk reduction from the 2015 Gorkha Earthquake and past seismic events within the Kathmandu Valley UNESCO World Heritage Property (Nepal)
}

\author{
Christopher Davis (iD) - Robin Coningham • Kosh Prasad Acharya • \\ Ram Bahadur Kunwar • Paolo Forlin • Kai Weise • Prem Nath Maskey • Anie Joshi • \\ Ian Simpson • David Toll • Sean Wilkinson • Paul Hughes • Vasilis Sarhosis • \\ Ashutosh Kumar • Armin Schmidt
}

Received: 31 May 2019 / Accepted: 29 October 2019/Published online: 4 December 2019

(C) The Author(s) 2019

\begin{abstract}
The 2015 Gorkha Earthquake was a humanitarian disaster but also a cultural catastrophe that damaged and destroyed historic monuments across Nepal, including those within the Kathmandu Valley UNESCO World Heritage Property. In the rush to rebuild, traditionally constructed foundations are being removed and replaced with modern materials without assessments of whether these contributed to the collapse of a monument. Generally undertaken without scientific recording, these interventions have led to the irreversible destruction of earlier subsurface phases of cultural activity
\end{abstract}

C. Davis $(\bowtie) \cdot$ R. Coningham $\cdot$ P. Forlin

Department of Archaeology, Durham University, Durham, UK

e-mail: christopher.davis@durham.ac.uk

\section{R. B. Kunwar}

Department of Archaeology, Government of Nepal, Kathmandu, Nepal

K. P. Acharya $\cdot$ K. Weise $\cdot$ A. Joshi

ICOMOS, Kathmandu, Nepal

P. N. Maskey

Institute of Engineering, Tribhuvan University, Kirtipur, Nepal

I. Simpson

School of Biological and Environmental Sciences, University of and the potential loss of evidence for successful traditional seismic adaptations and risk reduction strategies, with no research into whether modern materials, such as concrete and steel, would offer enhanced resilience. In response to this context, multidisciplinary post-disaster investigations were undertaken between 2015 and 2018, including archaeological excavation, geophysical survey, geoarchaeological analysis, linked to architectural and engineering studies, to begin to evaluate and assess the damage to, and seismic adaptations of, historic structures within Nepal's Kathmandu Valley. Where

Stirling, Stirling, UK

D. Toll $\cdot$ P. Hughes $\cdot$ A. Kumar

Department of Engineering, Durham University, Durham, UK

S. Wilkinson

School of Engineering, Newcastle University, Newcastle upon Tyne, UK

V. Sarhosis

School of Civil Engineering, University of Leeds, Leeds, UK

A. Schmidt

GeodataWIZ, Remagen, Germany 
possible, we draw on archaeoseismological approaches for the identification and classification of Earthquake Archaeological Effects (EAEs) at selected monuments damaged by the 2015 Gorkha Earthquake. Lessons learned from evidence of potential weaknesses, as well as historic 'risk-sensitive tactics' of hazard reduction within monuments, are now being incorporated into reconstruction and rehabilitation initiatives alongside the development of methods for the protection of heritage in the face of future earthquakes.

Keywords Kathmandu $\cdot$ Nepal $\cdot$ South Asia . Archaeolseismology · Earthquake Archaeological Effects (EAEs) · Resilience · Seismic adaptations · Rehabilitation

\section{Introduction}

The collision between the Indian and Eurasian plates which has formed the Himalayan mountain range also brings with it the constant threat of seismic activity. The city of Kathmandu, in the foothills of the Himalayas in Nepal, bears witness to thousands of years of cultural development and adaptation relating to this context. Seven monumental zones of the Kathmandu Valley, including the three medieval urban centres of Patan, Kathmandu and Bhaktapur, as well as major monumental religious complexes of Buddhist stupas at Swayambhu and Baudhanath, and Hindu Temples at Pashupati and Changu Narayan, were inscribed on the UNESCO World Heritage list in 1979 (Fig. 1). These sites, with their monumental ensembles, were recognised by UNESCO as exceptional representations of the unique and traditional architectural typologies and artistic achievements developed by societies within the Kathmandu Valley. There was also recognition of the continuation of these craft traditions of elaborate woodcarving and construction techniques incorporating timber, brick, tile and stone (http://whc.unesco. org/en/list/121/).

At 11.56 NST on April 25, 2015, the 7.8 magnitude Gorkha Earthquake ruptured a segment of the Main Himalayan Thrust fault (Rupakhety 2017: 19) and was followed by a series of powerful aftershocks, with the strongest at 7.3 magnitude tremor on the 12th of May 2015 (Varum et al. 2017: 47). It precipitated a humanitarian disaster that caused some 9000 fatalities, injured 22,000 and destroyed 498,852 residential buildings (Varum et al. 2017: 47). The earthquake was also a cultural catastrophe, causing destruction and damage to 691 historic buildings across Nepal, including 403 within Kathmandu's UNESCO World Heritage Property (Gautam et al. 2015: 3). However, this is not the first instance that these monuments, or their earlier developmental phases, have been damaged by earthquakes and that associated communities have reacted to and reconstructed their urban fabric and lives after such catastrophic events.

The early history of the Kathmandu Valley has largely been gleaned from textual sources including inscriptions from the fourth century CE onwards (Regmi 1983), manuscript colophons from the eight century CE onwards (Petech 1984) and Chronicles or vamiśāvalī such as the Gopālarājavamiśâvali dating from the fourteenth century onwards (Vajracharya and Malla 1985). Within this rich corpus of historical narrative, the Chronicles provide regular recording of major earthquakes, including those in CE 1224, 1255, 1260, 1344, 1408, 1681, 1767, 1823, 1833, 1834, 1869, 1916 and 1934 (Gautam et al. 2015: 1-3). Earlier accounts of seismic events are fairly generalised, for example, the record of the $1408 \mathrm{CE}$ earthquake stated that houses and temples were destroyed and that 'innumerable living beings perished' (Bajracharya et al. 2016: 83). The later Chronicles record far more detail in their assessments, with references to the 1833 Earthquake including the numbers of damaged houses and temples, including their levels of destruction, as well as tallies of casualties and fatalities in different parts of the Kathmandu Valley (Bajracharya et al. 2016: 139-140). During this later period, additional accounts are available from eyewitnesses, including the reports of Archibald Campbell, Assistant Surgeon at the British Residency in Kathmandu, which detail the reaction of society and authorities to the disaster, as well as broadly cataloguing casualties, fatalities and damage to houses and monuments (Campbell 2018: 17-22).

The last major earthquake of modern times, prior to the 2015 Gorkha Earthquake, was the 8.4 magnitude Bihar Earthquake of 1934 (Chaulagain et al. 2017: 7) and the account of Major General Brahma Shumsher J.B. Rana provided systematic lists of casualties and fatalities, as well as inventories of damaged and destroyed structures throughout Kathmandu and Nepal (Rana 1934). His narrative moved beyond records of previous earthquakes by providing observations and evaluations of the nature of damage to structures and 


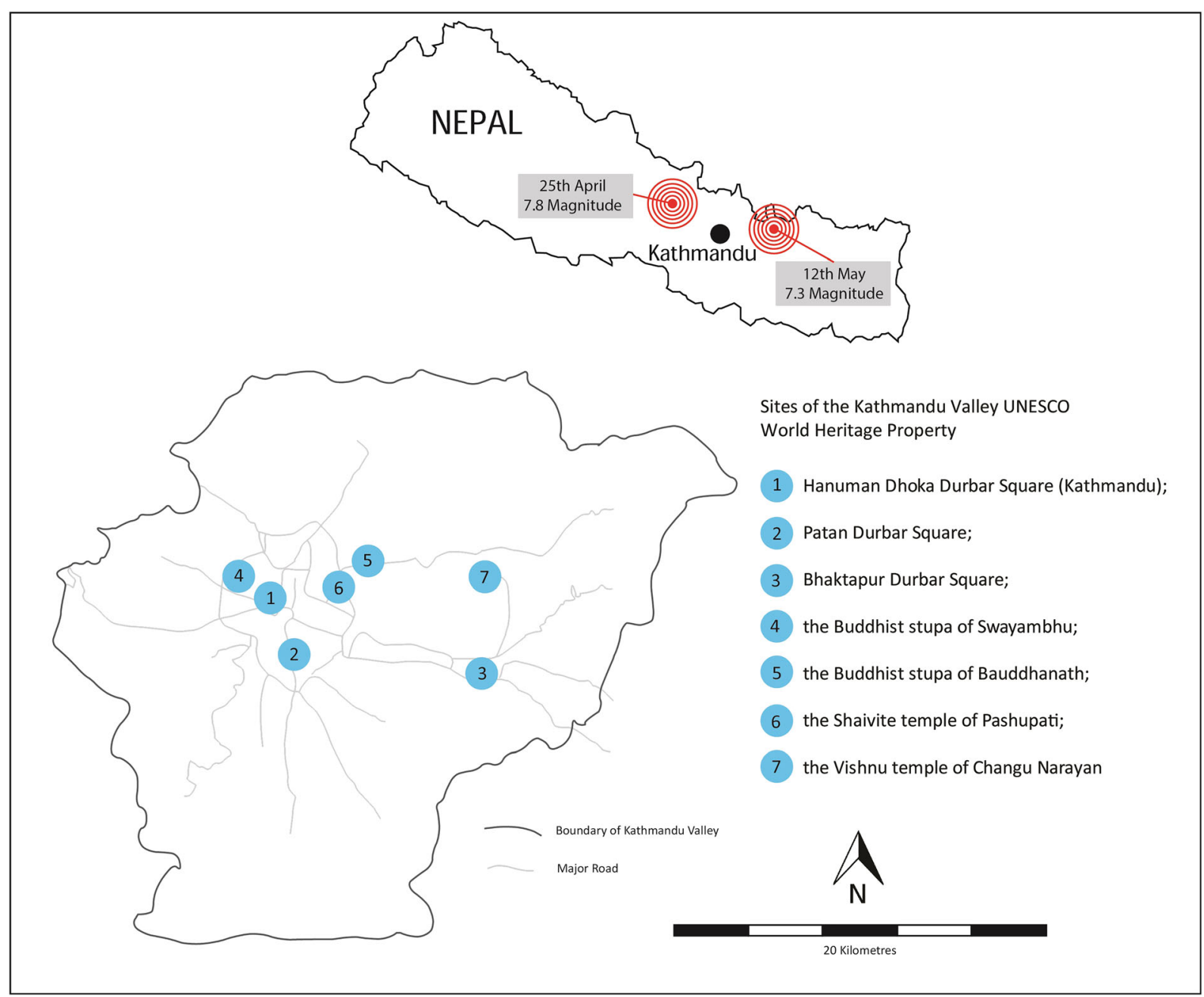

Fig. 1 Map of Nepal and inset showing location of monument zones comprising the Kathmandu Valley UNESCO World Heritage Property

began to frame suggestions for reconstruction and the reinforcement of buildings in the face of future seismic shocks (Rana 1934: Chapter 10). This could be argued to be the first recorded systematic attempt within Nepal to identifying potential earthquake damage patterns, and seismic adaptive strategies, although there is little documentation available and no comprehensive study has been undertaken to identify the actual recovery process from the 1934 earthquake (Weise et al. 2017: 67). Therefore, whilst we know that past societies had to react and adapt to earthquakes, and other short-term environmental shocks, there is negligible evidence of how this was actually undertaken or achieved in the past.

Whilst it has been recognised that there is a "need for collaboration between archaeologists, geologists, engineers and workers in other disciplines, to evaluate the traces of earthquakes in excavations, both for understanding their effects at the site and for the information they can provide about the nature of the earthquake implicated' (Ambraseys 2006: 1015), such collaboration has been in practice limited and seldom undertaken in contemporary disasters. Indeed, funding for such interdisciplinary research appears to have been focused on human-made heritage disasters rather than natural heritage disasters (Coningham and Weise 2019). As such, the aftermath of the 2015 Gorkha Earthquake thus offered an extremely rare opportunity to bring together archaeologists, geoarchaeologists, geophysicists, architects, engineers and local communities to begin to understand how a sample of historic monuments within the Kathmandu Valley was designed and engineered and to 
shed light on their origins and development, as well as to gather information that could be filtered into rehabilitation efforts to improve and monitor their seismic safety in the face of future earthquakes. In this paper, we discuss some of the initial findings to identify and contrast past and present examples of earthquake damage and resilience found within heritage structures of the Kathmandu Valley, and develop an understanding of Archaeological Earthquake Effects (EAEs) within the archaeological record of Nepal. As such, we also hope to demonstrate the potential of the multidisciplinary field of archaeoseismology, or earthquake archaeology, both within South Asia and within immediate postdisaster environments.

\section{The 2015 Gorkha Earthquake}

As noted above, the 2015 Gorkha Earthquake damaged 691 historic buildings across Nepal, including monuments located within Kathmandu's UNESCO World Heritage Property, with many collapsing (Fig. 2). Initial damage assessment and salvage efforts were undertaken by the newly established Earthquake Response Coordination Office within the Department of Archaeology (Government of Nepal), which was followed by the preparation of a Post-Disaster Needs Assessment (Weise et al. 2017: 72). Completed on the 10th of June 2015 by the Department of Archaeology and UNESCO Kathmandu, the Post-Disaster Needs Assessment (PDNA 2015) estimated the damage to Nepal's cultural heritage at about US\$169 million, with an associated loss of US\$23 million from damage and impact on livelihoods (PDNA 2015: 1). As major visitor attractions, partially accounting for the $7.6 \%$ of GDP generated by tourism to Nepal's Gross Domestic Product, and as foci for veneration, community gatherings and local markets, damaged heritage sites were subject to a major programme of consultation, reconstruction and conservation.

Prior to the Gorkha Earthquake, the majority of research into these monuments had been focused on the architectural and art historical documentation of superstructures, mostly dating from between the fifteenth and eighteenth centuries CE (e.g. Basukala et al. 2014; Gutschow 1997, 2011; Korn 2007, 2014; Hutt 1994; Prushca 2015). The PDNA and reconstruction efforts followed a similar trajectory centred on standing architecture, with no reference to the vulnerability of subsurface archaeological heritage of the Kathmandu Valley
World Heritage Property, or the need to study and scientifically analyse the foundations of monuments (Coningham et al. 2016a). Adopting a Build Back Better approach (PDNA 2015: 1), foundations of damaged structures were removed or dug into without recording, leading to a complete loss of evidence regarding the earlier archaeological sequence, but also removing evidence of seismic damage or adaptation patterns (Coningham et al. 2016a). This situation was exacerbated by rapid reconstruction efforts, the majority undertaken without any research into why a monument may have been damaged or collapsed. These interventions also privileged modern engineering and materials, such as concrete and steel, over traditional techniques and knowledge, and without an assessment of the seismic performance of the existing or new designs (Weise et al. 2017: 82; Coningham et al. 2018: 162).

In reaction to what we have termed a 'second cultural disaster' brought about by the process of indiscriminate clearing and reconstruction, a team of archaeologists, geoarchaeologists, geophysicists, architects and engineers was brought together between 2015 and 2018 to pilot post-disaster assessments and evaluations of selected monuments and their environs within the Kathmandu UNESCO World Heritage Property. With funding from UNESCO, the National Geographic Society as well as Arts and Humanities Research Council and British Academy Global Challenges Research Fund grants, with the support of the Department of Archaeology (Government of Nepal), UNESCO (Kathmandu), ICOMOS (Nepal) and the Pashupati Area Development Trust, our multidisciplinary team aimed to evaluate the nature and condition of the foundations of collapsed and damaged monuments, to assist with plans for reconstruction and rehabilitation, as well as identify earlier cultural sequences and phasing of monuments, which could be scientifically dated (Coningham et al. 2018: 164). In so doing, we also recognised the potential contribution of our research in Kathmandu to the emergent field of archaeoseismology and the identification of further examples for the growing corpus of EAEs.

\section{Archaeoseismology within South Asia}

Utilising evidence from the archaeological record to identify earthquakes within antiquity, archaeoseismology has been primarily focussed on reconstructing the chronology, magnitudes and epicentres of past earthquakes, 


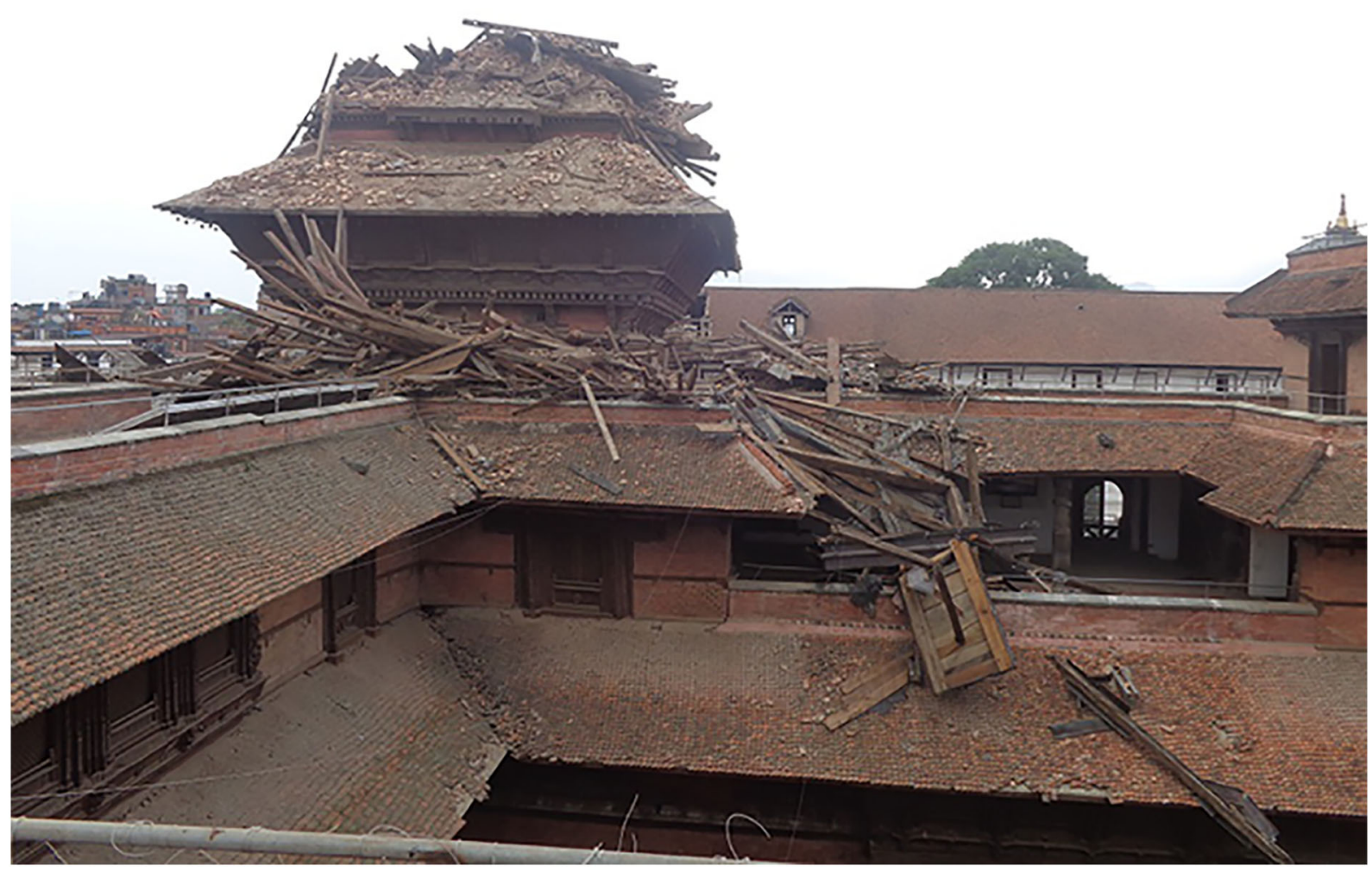

Fig. 2 Damage to the nine-storey palace in Hanuman Dhoka after the 2015 Gorkha Earthquake (image: Kai Weise)

developing an ancillary path for the preparation of historical seismic catalogues (Guidoboni and Ebel 2009: 418472). On the other hand, archaeology provides extraordinary evidence for the understanding of past seismic adaptation and preparedness (e.g. Forlin and Gerrard 2017 for late medieval Europe). Frequently, the starting point for such a study is the use of textual sources to identify locations and dates of historic earthquakes. South Asia is no exception, with the vast majority of recorded earthquake events in textual sources dating from the sixteenth century onwards (Bilham 2004). However, archaeoseismological methods can also be used to identify earlier earthquakes through distinctive damage patterns within excavated sequences, as well as assessments of the fabric of historic standing remains. Such archaeological evidence can be used to identify earthquakes where no textual records are present, or in an attempt to augment the usually poor time resolution of events recorded in textual sources (Ambraseys 2006; Galadini et al. 2006; Silva et al. 2011; Sintubin 2011; Stiros and Jones 1996).

One of the key challenges of archaeoseismology is to differentiate damage caused by earthquakes from other destructive events and catastrophes, including war and the effects of long-term abandonment (Giner-Robles et al. 2009: 13; Rodríguez-Pascua et al. 2011: 20). A classification of EAEs was initially developed by drawing on examples from Baelo Claudia, Cadiz, in southern Spain (Giner-Robles et al. 2009). This was then developed further with examples from sites in Europe, the Middle East and Meso-America (Rodríguez-Pascua et al. 2011). With reference to these examples, EAEs were then separated into primary effects (both structural and geological) and secondary effects. Primary geological effects include seismic uplift, subsidence and fault scarps, as well as evidence of liquefactions and dike injections, landslides and rock falls. Primary effects on building fabric include strain from ground deformation, such as folded pavements, displaced and rotated masonry blocks, fractures and cracks through masonry blocks and walls, as well as tilted and collapsed walls, sometimes with artefacts or human remains found sealed beneath. Post-seismic secondary effects include fires, flash floods from collapsed dams, phases of abrupt abandonment, including stratigraphic gaps within the archaeological record, and evidence of the reuse of 
materials and repair of buildings. This includes situations in which collapsed structures were subsequently levelled and new structures built over the top, or areas cleared and left as open ground. Although catalogues have focussed mainly on examples from Europe, the Middle East and Meso-America, potential EAEs have previously been identified within archaeological sequences of South Asia, as discussed below.

\subsection{Primary effects}

A number of geological effects from earthquakes have been identified within archaeological sequences excavated in South Asia. For example, there are several examples of sandblows in the Indian state of Gujarat, an effect associated with liquefaction. These include those at Bet Dwarka, within archaeological horizons dating to the turn of the first centuries BCE/CE (Rajendran and Rajendran 2003), but also within archaeological sequences at the Bronze Age Indus Valley site of Lothal (Rajendran et al. 2008: 12). Similar indications of liquefaction were identified at Biharigarh in Uttar Pradesh, where excavations revealed out of sequence fine sand layers. Radiocarbon determinations from the lowest and thickest band of these fine sand horizons suggest that these effects may relate to the 1803 CE Garhwal Earthquake (Rajendran et al. 2013: 1104). Further geological effects, including slip faults, fault rupture and displacement of archaeological sediments suggestive of seismic activity have also been recognised in the sections of excavations at Indus Valley civilisation sites such as at Kalibangan and Dholavira (Kovach et al. 2010: 124-125).

Primary EAEs linked to damage in structures have also been reported at several sites across South Asia. These include the presence of crushed human remains within rubble at Mansurah in Sindh, Pakistan, and attributed to the destruction of the city by an earthquake in c. 980 CE (Bilham and Lodi 2010). Within excavated sequences at Dholavira, tilted walls have been identified (Kovach et al. 2010: 124) and at Barikot (Bir-Kotghwandai) in Swat, Pakistan, collapsed walls and cracks across walls have been associated with multiple earthquake events up until the third century CE (Olivieri 2015: 197-198). Assessments of standing buildings have also identified EAEs, with characteristic out-ofplane displacement of stone blocks found in temple constructions in Kashmir (Bilham and Bali 2014); twisted and tilted walls, as well as rotation and fractures in architectural features at Temples within Kamaun Province and Garhwal Division in the Himalayas (Rajendran et al. 2013), and in seventeenth-century CE temples in Chamba District, Himal Pradesh, India (Joshi and Thakur 2016).

Earthquakes have also been identified as possible factors in the reconfiguration and reuse of materials within monuments, particularly Gandharan sites in $\mathrm{Pa}$ kistan. Although difficult to determine, it has been suggested that within this region rich in Buddhist heritage, a destructive earthquake occurred at some point in the third century CE. This has been postulated on account of the presence of many earlier large and damaged stone schist carved images and reliefs within later relic shrines at several monastic sites in the region as well as many re-contextualised narrative panels in a fragmentary condition (Behrendt 2009: 20). Behrendt (2009) notes that earlier scholars have also identified earthquake damage in the region, with Sir John Marshall suggesting that the urban form of Taxila was 'visited by a violent earthquake' (Marshall 1951: 63) during the early first century $\mathrm{CE}$, with evidence for a seismic event represented by the collapse of monuments and split stone blocks. Marshall also suggested that the inhabitants reacted to this seismic event by developing more earthquake-resistant building methods in its aftermath (Marshall 1951: 63). This theme of rebuilding and reconstruction has been noted at Barikot, where several separate instances of earthquake damage and repair have been identified throughout the history of the site (Callieri et al. 1992: 10-11). This is clearest at the Buddhist Shrine Structure [527] in Court 28, where the archaeological sequence has been interpreted as a narrative for the effects, and responses to, seismic damage. It has been suggested that an earthquake caused the collapse and destruction of Structure [527]. This material was then levelled and a newer structure of timber with a canopy was built over the top. It is then postulated that a final collapse of the structure may have been caused by a further earthquake, at some point from the third century CE (Olivieri 2011: 8).

\subsection{Secondary effects}

Secondary effects have also been identified in South Asia's archaeological record, with phases of abandonment at settlements linked to the aftermath of earthquakes. For example, evidence of a short-term abandonment at the Bronze Age Indus Valley site of Kalibangan, 
with infertile windblown sand covering a phase of settlement, has been attributed to the impact of an earthquake, with the hiatus later followed by re-settlement (Kovach et al. 2010: 124). Major and final abandonments of settlements have also been ascribed to earthquakes, as with the end of occupation at Barikot in the third century CE (Olivieri 2011: 11). However, it must be noted that other factors may have led to the abandonment and reoccupation of settlements, as noted with regard to the later phases of the Indus Valley tradition's urban decline (Coningham and Young 2015: 263-275). Indeed, secondary effects may have more long-lasting impacts on society and it has been suggested that the recorded famine following the $1260 \mathrm{CE}$ earthquake in Nepal was the major cause of casualties rather than the earthquake itself (Chaulagain et al. 2017: 1). Within Kashmir, historical accounts record that earthquakes were the causes of secondary effects such as landslides and flooding in the medieval period, which also caused periods of famine (Bilham and Bali 2014: 81). However, it has also been suggested that societies can sometimes experience benefits from such effects. For example, it has been argued that the creation of lakes and higher water levels from landslides in Kashmir may have aided transport and the movement of raw materials, leading to a proliferation of temple construction within this region during the late ninth and early tenth centuries $\mathrm{CE}$ (Bilham and Bali 2014: 91-93).

\subsection{Summary}

Whilst the majority of the case studies utilised to develop the framework of EAE classification are European-, Middle Eastern- and Meso-Americanfocused, these selected examples provide evidence of both primary and secondary EAEs identified within archaeological sequences and standing monuments within South Asia. Although EAEs are more readily identified within monumental standing stone constructions, evidence from the archaeological record in South Asia indicates the potential for identifying seismic damage within archaeological sequences and brick-built structures. Certainly, there is a need to further develop the catalogue of EAEs for other traditional building structures, including those with timber frames and brick infills and comparator examples from contemporary observations may aid the identification and confirmation of such damage patterns within the archaeological record.

\section{Identifying EAEs from the 2015 Gorkha Earthquake in Kathmandu}

During our post-disaster investigations, the team undertook a small survey of selected monuments within the Kathmandu Valley UNESCO World Heritage Property to assess and identify EAEs from the 2015 Gorkha Earthquake, as well as potential historic EAEs visible within standing structures. These were undertaken to provide a catalogue of general EAEs that could be identified and used as frames of reference for potential EAEs within archaeological sequences. In addition to obvious earthquake-related damage, such as rubble from collapsed walls, EAEs were visible at many heritage sites and the following provides key illustrations from the survey from the large number of examples available across the Kathmandu Valley.

Tilted walls, close to collapse, were found at several structures, including a clear example at a building within the Mrigasthali area of Pashupati (Fig. 3a). Of monuments where full collapse had not occurred, fractured walls, including shear cracks and ' $\mathrm{X}$ ' fracture patterns through wall facades were common at stone and brick structures, particularly wood-framed buildings with brick infills. Occasionally, these cracks were caused by wall extrusions across the facades of structures. Examples of fracturing were found, but were not limited to, structures in Mrigasthali (Fig. 3b), the Jagannath temple in Hanuman Dhoka's Durbar, or palace, Square and at structures within Bhaktapur's palace complex (Fig. 3c). At Pashupati, in some instances, it was possible to identify vertical cracks linked to the displacement of walls. More complex patterns of cracks were identified at the Shiva temple located within Hanuman Dhoka Durbar Square. Here, there was evidence of composite shear cracks associated with the extrusion of a wall, with the wall profile also appearing to be folded. Such seismic damage patterns are caused by horizontal motion, but there was also a strong vertical component present, testified by sub-vertical fractures penetrating vertically. These EAEs were found at the base of the shrine, which is not entirely surprising due to 

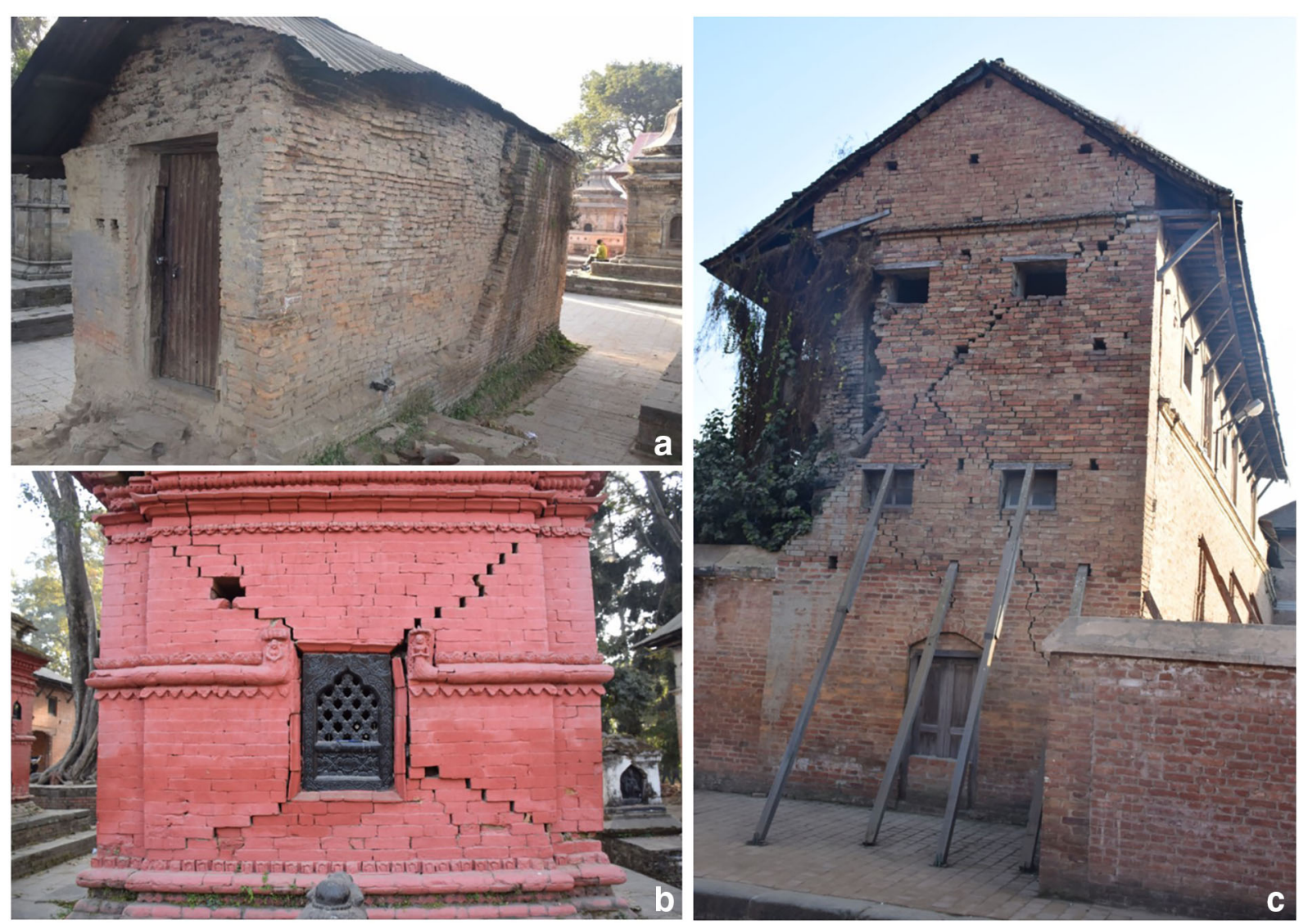

Fig. 3 Tilted wall at a structure at Mrigasthali in Pashupati (a); 'X fracture through a brick built shrine at Mrigasthali in Pashupati (b); shear cracks through one of the walls within Bhaktapur Palace Complex (c)

this being the location where architectural stresses would be higher. Extrusions and the shifting of masonry blocks was also identified, both at collapsed monuments such as the Vatsala Temple in Bhaktapur (Coningham et al. 2016b), but also within the lion statues that are located just within the western gateway of Bhaktapur's Durbar Square, which now flank the entrance to the Shree Padma Secondary High School (Fig. 4).

Some EAEs identified may relate to earlier seismic events as clearly identified at the Kotillingeshwor Mahadev Temple within Hanuman Dhoka's Durbar Square. On the plinth of the monument cracks formed from vertical force are present, with stone blocks cracking, as well as blocks laid next to each other being pushed apart. A second and later phase was then built on top of this stone plinth, which suggests that an earlier structure may have collapsed, possibly due to an earthquake, and the current superstructure built on top. Evidence from Bhaktapur suggests that such a scenario is not uncommon in Kathmandu, where a new shelter for a shrine was erected quickly on top of a surviving brick plinth (Coningham et al. 2016b), which will be further discussed below.

\section{EAEs identified previously within archaeological sequences of the Kathmandu Valley}

In addition to these observations, prior excavations in the Kathmandu Valley have uncovered evidence of EAEs. From excavations conducted at Dumakhal, a settlement located close to Changu Narayan, the debris from collapsed structures, uncovered towards the later stages of the archaeological sequence, is attributed to a major earthquake at some point in the thirteenth and fourteenth centuries CE (Khanal and Riccardi 2007: 48).

Furthermore, a range of EAEs, from a series of postulated seismic events, were identified during excavations within Harigaon (Verardi 1992). The first 
Fig. 4 Shifted and extruded stone blocks in a lion sculpture at Bhaktapur
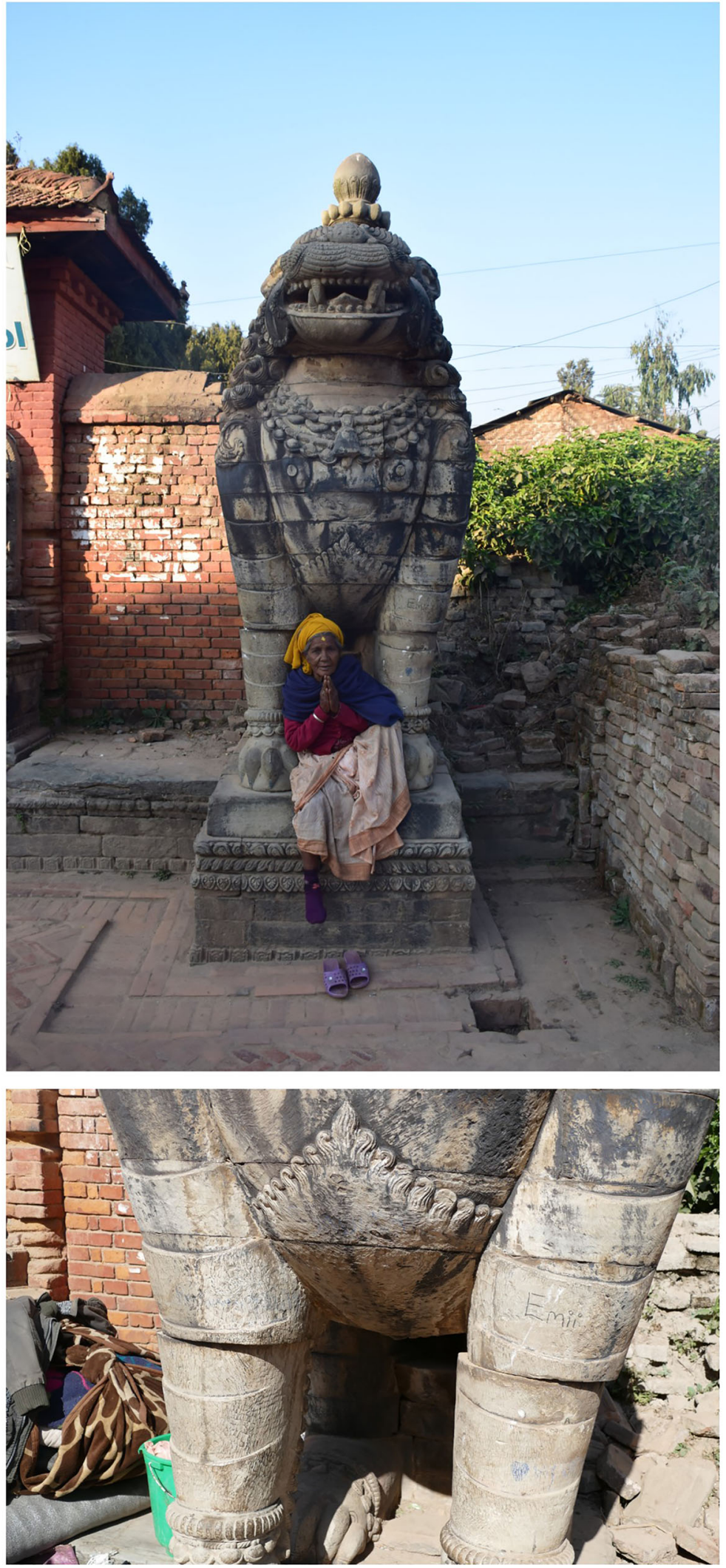

勧 Springer 
occurred at some point around the sixth and seventh centuries CE and primary effects included the identification in the stratigraphy of a 'fault plane typical of a violent earthquake' (Verardi 1992: 68), as well as what appears to be a large shear crack running down brick wall 131 of Structure 1 (Verardi 1992: 67). After this earthquake event, secondary effects were reported, such as the renovation and reconstruction of the seismically damaged Structure 1 (Verardi 1992: 79). Both primary and secondary effects were then noted for a second seismic event, which was deemed responsible for the subsidence of an area of paving and a floor level, with tiles from debris reused for repair as a levelling material (Verardi 1992: 91-92). Finally, both primary and secondary effects were recognised in relation to 'an extremely violent earthquake' (Verardi 1992: 100), near the end of the occupied sequence of the site at some point in the fifteenth to sixteenth centuries CE. A fissure through a pavement and collapsed structures were identified (Verardi 1992: 100-101), with post-earthquake reuse of materials from these damaged buildings found in later smaller constructions (Verardi 1992: 102).

In combination with the classification of EAEs developed from examples in Europe, the Middle East and Meso-America, as well as examples from previous studies within South Asia and both the standing architecture and previously excavated sequences of the Kathmandu Valley, we were able to identify possible EAEs during the evaluations and assessments of foundations and earlier cultural sequences, conducted adjacent to collapsed monuments within the Kathmandu Valley (Table 1).

\section{EAEs identified in archaeological sequences during post-disaster investigations in the Kathmandu Valley}

Through a combination of geophysical survey, excavation and geoarchaeological analysis, we identified several further examples of potential primary EAEs, as well as adaptive strategies and responses employed by societies in antiquity to seismic activity, during our postdisaster fieldwork within the Kathmandu Valley UNESCO World Heritage Property.

Reconfiguration of space is one potential response to a seismic event (Forlin and Gerrard 2017: 99), with collapsed structures levelled and areas left clear or new structures built directly over the top of the earlier, demolished buildings. A combination of geophysical survey, through Ground Penetrating Radar (GPR), and targeted excavation facilitated the investigation of such a situation within the large Durbar Squares, and temple and palace courtyards of the Kathmandu Valley. GPR survey with a Mala $500-\mathrm{MHz}$ system, mounted on a rough-terrain cart, measuring vertically downwards, on transects spaced $0.25 \mathrm{~m}$ apart, was undertaken in grids. The GPR facilitated the identification of anomalies across horizontal and vertical planes, identifying the depth and spread, and potential character, of these features below areas that are currently open spaces. GPR survey was conducted at the three main Durbar Squares of Hanuman Dhoka, Patan and Bhaktapur. In addition to identifying modern features, such as pipes and electric cables, our GPR surveys illustrated that rather than being empty, a number of anomalies were present that represented earlier structures, sealed below the now open and paved surfaces.

This was clearest in Bhaktapur's Durbar Square, where several rectilinear anomalies were identified. Their shape, size and overall layout suggest walls for a building that may have stood in this place. Excavations across the Durbar Square identified several east-west and north-south wall alignments, sealed below herringbone paving thought to be laid after the 1934 Bihar Earthquake (Fig. 5). The location and nature of these features suggest that these remains most likely represent the foundations of the Lamupati, a two-storey sattal (Coningham et al. 2016b). Known from early twentieth-century photographs as well as watercolours painted by Henry Ambrose Oldfield and drawings by Rajman Singh from the mid-nineteenth century, this structure with a postulated construction date of c. 1750 CE (Bajracharya et al. 2016: 82, 85) collapsed in the 1934 earthquake and was not rebuilt. The levelling of damaged structures, which were then sealed below what became open spaces, is not unique to the Kathmandu Valley and is a reaction to earthquakes that have been noted in medieval Europe. For example, in Padua, Italy, within the Piazza Duomo, damaged structures were levelled and overlaid with paving during a programme of redevelopment in response to an earthquake dated to 1117 CE (Forlin and Gerrard 2017: 99).

Bhaktapur's Durbar Square after the 1934 Bihar Earthquake provides several examples of differing responses to reconstruction after the same seismic event. Whereas the Lamupati was dismantled and its foundations sealed below paving, the plinth and stone lions of 
Table 1 EAEs identified in South Asia and the Kathmandu Valley

\begin{tabular}{|c|c|c|c|c|}
\hline \multicolumn{3}{|c|}{ EAES } & \multirow{2}{*}{\begin{tabular}{|l|} 
Archaeological Examples in South Asia \\
Kalibangan (Kovach et al. 2010); Dholavira (Kovach et al. 2010)
\end{tabular}} & \multirow{2}{*}{$\begin{array}{l}\text { Example in the Kathmandu Valley UNESCO World Heritage Property (Visible in } \\
\text { Standing Remains \& From Excavation) } \\
\text { Harigaon (Verardi 1992: 68, 91, 100-1011 }\end{array}$} \\
\hline \multirow{10}{*}{ Primary Effects } & \multirow[b]{2}{*}{ Geological Effects } & Seismic uplift/subsisdence & & \\
\hline & & Liquefaction and dike injections & $\begin{array}{l}\text { Bet Dwarka (Rajendran and Rajendran 2003); Lothal (Rajendran et al. } \\
\text { 2008); Biharigarh (Rajendran et al. 2013) }\end{array}$ & . \\
\hline & \multirow{8}{*}{ Building Fabric Effects } & Tilted Walls & $\begin{array}{l}\text { Dholavira (Kovach et al. 2010); Barikot (Olivieri 2015); Kamaun Province } \\
\text { and Garhwal Division (Rajendran et al. 2013) }\end{array}$ & Mrigasthall, Pashupati jaisidewal Temple \\
\hline & & Rotated and displaced masonry blocks & $\begin{array}{l}\text { Temples within Kamaun Province and Garhwal Division (Rajendran et al. } \\
\text { 2013) }\end{array}$ & . \\
\hline & & Displaced Masonry Blocks & $\begin{array}{l}\text { Sites in Kashmir (Bilham and Bali 2014); Kamaun Province and Garhwal } \\
\text { Division(Rajendran et al. 2013) }\end{array}$ & $\begin{array}{l}\text { Vatsola Temple, Bhaktapur; Lion Statues, Bhaktapur; Kotilingeshwor Mahadev } \\
\text { Temple, Hanuman Dhoka Durbar Square }\end{array}$ \\
\hline & & \begin{tabular}{|l} 
Folded Walls \\
\end{tabular} & & Shiva Temple, Hanuman Dhoka Durbar Square; Jaisidewal Temple \\
\hline & & Displaced Walls & . & $\begin{array}{l}\text { Laisidewal area } \\
\end{array}$ \\
\hline & & \begin{tabular}{|l|} 
Penetrative Fractures in masonry blocks \\
\end{tabular} & Barikot(Olivieri 2015); Taxila (Marshall 1951) & Kotillingeshwor Mahadev Temple, Hanuman Dhoka Durbar Square \\
\hline & & $\begin{array}{l}\text { Conjugated fractures in walls, including ' } X \text { ' and } \\
\text { shear cracks }\end{array}$ & $\begin{array}{l}\text { Barikot (Olivieri 2015); Temples within Kamaun Province and Garnwal } \\
\text { Division (Rajendran et al. 2013); temples in Chamba District (Joshi and } \\
\text { Thakur 2016) }\end{array}$ & $\begin{array}{l}\text { Mrigasthali, Pashupati; Superstructure of Jagannath temple and Shiva temple, } \\
\text { Hanuman Dhoka Durbar Square; Bhaktapur Palace; Kotillingesh wor Mohodev } \\
\text { Temple, Hanuman Dhoka Durbar Square; Jaisidewal Temple; Harigaon (Verardi } \\
\text { 1992: 67) }\end{array}$ \\
\hline & & Collapsed Walls & Mansurah (Bilham and Londi 2010); Barikot (Olivieri 2015) & $\begin{array}{l}\text { For examples across the Kathmandu Volley see: Gautam et al. (2015). Bhaktapur; } \\
\text { Harigaon (Verardi 1992: 100-101); Dumakhal (Khanal and Riccardi 2007: 48). }\end{array}$ \\
\hline \multirow{7}{*}{\multicolumn{2}{|c|}{ Secondary Effects }} & Settlement Abruptly Abandoned & Barikot (Olivieri 2011) & \\
\hline & & Recycling Anomolous Elements & Gandhara (Behrendt 2009) & 55 windowed paiace, Bhaktapur \\
\hline & & Repaired/Rebuilt Buildings & Gandhara (Callieri et al. 1992); Barikot (Olivieri 2011) & $\begin{array}{l}\text { Silu Mahadev (Fasu Dega) temple, Bhaktapur; Kotillingeshwor Mahadev Temple, } \\
\text { Hanuman Dhoka Durbar Squore; Traillokiva Mohan Temple, Hanuman Dhoka } \\
\text { Durbar Square; Maju Dega Temple, Hanuman Dhoka Durbar Square; Vatsala } \\
\text { Temole, Bhaktapur Durbar Square, Harigaon (Verardi 1992: 79, 92, 102) }\end{array}$ \\
\hline & & Flash floods & Kashmir (Bilham and Bali 2014) & \\
\hline & & Stratigraphic Gap in the Archaeological Record & Kalibangan (Kovach et al. 2010) & 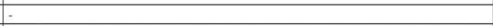 \\
\hline & & Anti-Seismic Buildings & Taxila (Marshall 1951) & $\begin{array}{l}\text { Foundations of the Kasthamandap, Jagannath temple, Gopinath temple, Trailokiva } \\
\text { Mohan temple, all Hanuman Dhoka Durbar Square; Vatsala Temple, Bhaktapur } \\
\text { Durbar Square; Char Naravan Temple, Patan Durbar Square }\end{array}$ \\
\hline & & Re-use/Reconfiguration of Space & . & $\begin{array}{l}\text { Bhaktapur Durbar Square; Patan Durbar Square; Hanuman Dhoka Durbar Square; } \\
\text { Hanuman Dhoka Palace: Changu Narayan Temple courtyard }\end{array}$ \\
\hline
\end{tabular}

the Hari Shankar temple were retained, whilst the superstructure was never rebuilt, possibly due to the loss of the sculpture of the main deity (UNESCO 2015: 40). The reuse of debris in reconstruction and new construction efforts has been viewed as evidence of a rehabilitation response after an earthquake (Forlin and Gerrard 2017: 99), and whilst some monuments were initially rebuilt with salvaged materials in slightly new configurations, such as the 55-windowed palace (UNESCO 2015: 40), other monuments were reconstructed quickly with completely new designs. The Silu Mahadev, located on the plinth of the original Fasu Dega (Tahacho Dega) Temple, just to the north of the Hari Shankar temple, had a Neo-Classical style whitewashed plaster dome with floral motifs constructed on the earlier monumental five-stepped brick plinth, with stone depictions of elephant guardians, and stone lions and bulls on the steps above (UNESCO 2015: 40). Other structures within Bhaktapur's Durbar Square were reconstructed several decades later, utilising modern materials, such as the Chyasilin Mandap (Gutschow and Hagmuller 1991). With historic photographs and records, as well as occurring in a timeframe of living memory for some inhabitants of the Kathmandu Valley, the changes effected and responses after the 1934 Bihar Earthquake in Bhaktapur can be identified. However, our archaeological investigations identified similar practices that are not recorded in any historical accounts from a deeper time-depth.

Within Patan's Durbar Square, our GPR survey identified several anomalies below the current paving, and excavations not only revealed a clay platform adjacent to the collapsed Char Narayan Temple but also a portion of a brick wall sealed below an earlier phase of paving. One of the raised areas of paving that formed the Square was also laid on an earlier tiled paving, which itself was set on homogenous levelling material, which included large quantities of rubble, including brickbats and broken tiles. There is a potential that much of this material indicates evidence of earlier earthquake damage, where material from surrounding damaged structures was repurposed for levelling and reconfiguring Patan's Durbar Square's layout (Coningham et al. 2016c).

Such reconfigurations were not limited to the Durbar Squares, and GPR survey identified several linear anomalies below the courtyards within the Palace Complex at Hanuman Dhoka. Within the courtyard of Nasal Chok, there were indications of potential robbed-out walls, as well as potential platforms sealed below the paving within this courtyard. Within the courtyard of Lam Chok, a further anomaly was identified, which may represent an earlier wall phase. The existence of earlier wall phases within the palace complex has now been confirmed through excavations conducted by the Department of Archaeology (Government of Nepal) (pers. com. Ram Bahadur Kunwar and Bhaskar Gyawali). Similarly, within the open courtyard of Changu Narayan Temple, substantial rectilinear anomalies, with a width of c. $1.5 \mathrm{~m}$, may represent the remains of collapsed walls or foundations. Subsequent excavations within the complex identified earlier structures and pavements below two distinct phases of levelling. The last phase of levelling covered a small brick wall, which 
in turn sat on an earlier levelling phase containing brick, tile and stone. This levelling sealed a brickbat paving and a large robbed-out stone wall. Below this brickbat paving, earlier cultural phases were identified. Changu Narayan is purported to be one of the oldest locations of habitation in the Kathmandu Valley and is known to have undergone many phases of construction and reconstruction from its origins through to the present day. However, at present, with all these examples, it is not possible to directly attribute such reconstruction episodes to specific events. It is also not possible to state whether such reconfigurations directly relate to earthquakes, though such events may provide the opportunity for major programmes of reconstruction.

Furthermore, our archaeological investigations have demonstrated that several current standing structures were erected directly on top of earlier phases. For instance, the footprint of the current stone-clad Vatsala temple within Bhaktapur's Durbar Square, thought to date to between the late seventeenth and early eighteenth century CE (Korn 2014: 29-33, 44, Basukala et al. 2014: 33), is off-set from the brick foundations below. These foundations step out to the west, whilst the superstructure overhangs this lower alignment to the south (Fig. 6a). This suggests the strong possibility of two quite separate phases of construction (Coningham et al. 2016b). Similarly, within Hanuman Dhoka's Durbar Square, we found that the current monumental plinths of the Maju Dega (Fig. 6b) and Trailokiya
Mohan Temples (Fig. 6c, d) had been built directly over earlier phases of construction (Coningham et al. 2018: 165). The scientific date for a structure identified running under the west of the Trailokiya Mohan temple, extracted from an Optically Stimulated Luminescence sample of the soil forming the wall's construction surface, was $1040 \pm 120 \mathrm{CE}$. This is around 600 years prior to the traditional date of $1679 \mathrm{CE}$ for the monument constructed above. This earlier wall may relate to a monument that was cleared to make way for its development (Hutt 1994: 85), although whether this earlier monument was damaged by earthquakes is not clear as the traditional construction date is slightly prior to the historic record of the $1681 \mathrm{CE}$ earthquake. Such a scenario may be more plausible for the Maju Dega temple, with construction traditionally ascribed to 1690 CE (Hutt 1994: 88), and would link to the proliferation of large stepped plinth temples in the Kathman$\mathrm{du}$ Valley in the late seventeenth century (Tiwari 2009). However, without historic records and until clearer scientific dating sequences are available, such an assertion is conjectural and it is not possible to link these episodes of levelling or reconstruction definitively as responses to seismic events. However, it remains a possibility alongside other opportunistic reasons for remodelling urban space.

Clearer evidence of EAEs has been uncovered in some of the excavated sequences within the Kathmandu Valley. A brick wall, thought to relate to the collapsed Lamupati,

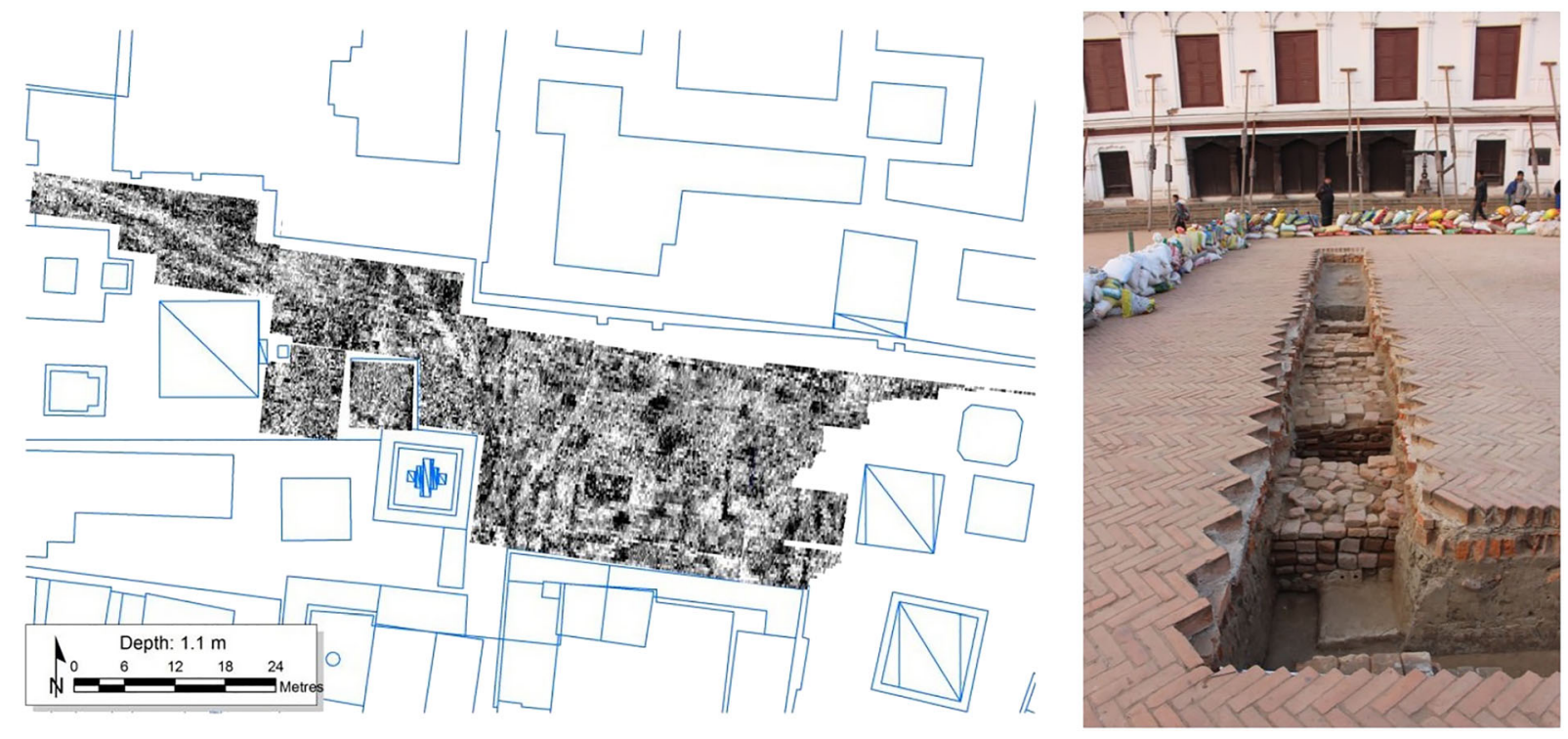

Fig. 5 GPR survey results at Bhaktapur Durbar Square at 1.1-m depth (left) and walls identified through excavation below the paved square (right) 
which was subsequently sealed below the paving of Bhaktapur Durbar Square after the 1934 Bihar Earthquake, had a significant penetrative fracture, whilst a further wall had collapsed and tilted to the east (Coningham et al. 2016b). The other major evidence of EAEs within the Kathmandu Valley are from excavations conducted at Jaisidewal Temple, and its environs. Located to the south of Hanuman Dhoka's Durbar Square, the three-tiered Temple's superstructure collapsed during the 2015 Gorkha Earthquake, with its seven-stepped plinth remaining largely intact. Excavations were undertaken to identify the condition of the foundations of the monument as well as the construction character of its massive stepped-plinths prior to reconstruction. Within a targeted area, excavations revealed that the monument had a massive brick core, which was dated to around the eleventh century $\mathrm{CE}$ through Optically Stimulated Luminescence dating. A further circuit of brick wall formed an outer foundation, which appeared to have been buttressed by another wall on its exterior at a later date (Strickland 2017). This outer part of the foundation appears to be deformed and tilted towards the exterior, with a folded profile due to a likely seismic horizontal load (Fig. 7). It is postulated that a later wall was constructed against the damaged structure in an attempt to strengthen and reduce the stress on this architectural feature. The current plinths post-date this to around the sixteenth century, encasing these episodes of construction, strengthening and repair.

To the southwest of the temple, a further trench was opened to record archaeological sequences prior to the drilling of geotechnical boreholes into natural soil profiles. Here, we identified a series of earlier brick wall alignments exhibiting EAEs, though unfortunately it was not possible to provide specific scientific dates for when this damage occurred. An east-west running wall, which was one brick thick, exhibited a shear crack and slight extrusion (Fig. 8a). A further brick wall running northsouth, to the east of the alignment with the shear crack, tilted towards the west with several courses collapsing in antiquity to form a rubble spill (Fig. 8b). This wall was then abutted at its south by an east-west wall, which was fractured, with a large crack causing the wall to displace, break in two and lean outwards towards the northwest. Directly below this wall, and from an earlier phase, was an earlier east-west brick wall alignment, which also leaned and tilted towards the north (Fig. 8c). Though archaeological evidence for such damage may not always relate to earthquakes (Ambraseys 2006: 1009), a number of factors support this hypothesis. Not only located within a seismically active zone, preliminary geotechnical assessment from borehole drilling of the underlying natural soil at the base of Jaisdewal's sequence has been identified as soft and conducive to seismic wave amplification during an earthquake (Coningham et al. 2019: 64).

The damage exhibited at the Jaisedewal Temple might suggest that the traditional building technique of mud mortar and brick foundations was not seismically resilient. However, monuments with similar foundation construction across the Kathmandu Valley have not been found to display EAEs. Indeed, the longevity of settlement in the Kathmandu Valley suggests a resilience within architecture and design in the face of regular earthquakes. Therefore, as the following section will outline, it is critical that archaeological rescue excavations and assessments are undertaken to understand traditional construction techniques and also ascertain why monuments may have been damaged or collapsed in certain locations, particularly when linked to local geological conditions.

\section{Identifying seismic adaptations}

Though EAEs were identified within the archaeological sequences at, and nearby to Jaisidewal Temple, and whilst it is clear that many historic structures were destroyed or damaged during the 2015 Gorkha Earthquake, our investigations to assess causes of collapse, evaluate foundations and record earlier cultural phases, suggest that traditional construction techniques of monuments in the Kathmandu Valley were exceptionally resilient. Our major programme of work was conducted at the Kasthamandap, the monument from which Kathmandu derives its name, and uncovered what have been defined as 'risk-sensitive tactics' and adaptations (Bankoff 2015; Kázmér 2019; Kázmér et al. 2010; Langenbach 2007) implemented by those who originally constructed and maintained the monument.

Originally designed as a sattal, or public rest house, providing shelter for pilgrims and traders close to the southern edge of Hanuman Dhoka's Durbar Square, the Kasthamandap may have also been the site where royal coronations occurred. Within its centre was a shrine to Gorakhnath and in the twentieth century, parts of the structure were utilised for shop and residential units. The earliest reference to the Kasthamandap is from a manuscript dated to $1143 \mathrm{CE}$ and whilst some have argued for a relatively late date of 1596 CE (Bernier 1970: 145), a 


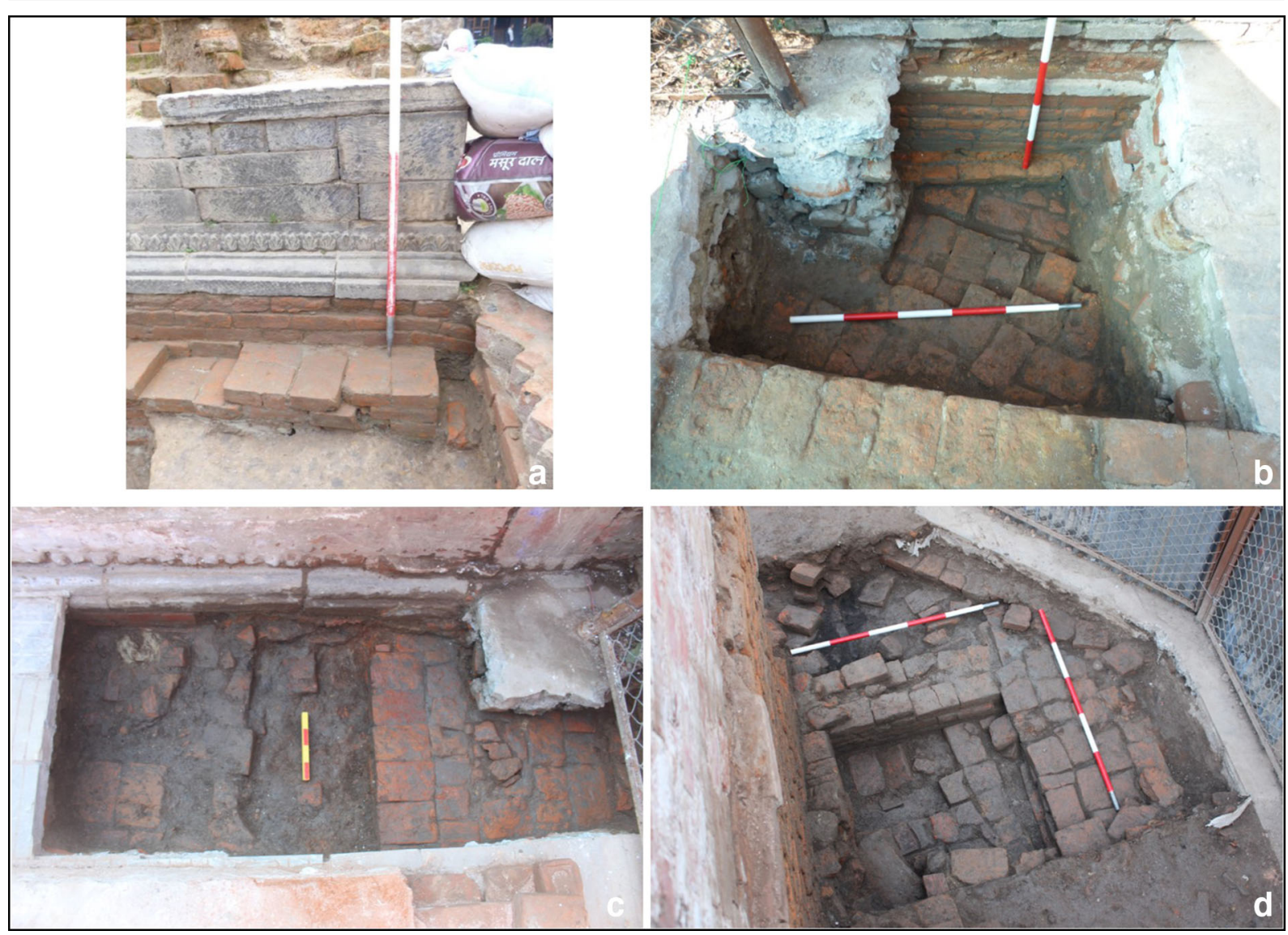

Fig. 6 The current footprint of the Vatsala Temple in Bhaktapur overlaying and overhanging an earlier brick foundation (a); a large brick wall on a differing alignment running under the plinths of the

majority suggest a date around the twelfth century CE, with it traditionally ascribed as one of the earliest standing monuments within the Kathmandu Valley (e.g. Amatya 2007: Thapa 1968: 33; Korn 2007: 128; Slusser and Vajracarya 1974: 207; Hutt 1994: 81).

As a major architectural icon of the Kathmandu Valley, the government, municipal authorities and local community groups pledged to reconstruct the monument rapidly after its complete collapse during the 2015 Gorkha Earthquake (Coningham et al. 2018: 168). In advance of this, excavations were undertaken to assess why the monument had collapsed and to provide information on damage to foundations that could inform reconstruction and rehabilitation initiatives. During two field seasons of excavations, a comprehensive picture of the traditional design and seismic adaptations, as well as historical development of the monument, was exposed and recorded.
Maju Dega Temple, Hanuman Dhoka (b); a structure located below the Trailokiya Mohan Temple to the east (c); and a further structure identified to the south (d)

Collapsing during the hosting of a temporary blood donation clinic, efforts to recover the trapped, injured and dead included the use of heavy machinery. During our excavations, we found evidence of the damage caused by this post-earthquake emergency intervention in the form of dug-out foundations and scrape marks scoring the surface of the tiled floor (Coningham et al. 2016d). This floor had been laid around several saddle stones, which contained sockets to interconnect with the tenons of the wooden superstructure. In particular, the four major wooden pillars of the Kasthamandap were linked to four large saddle stones around the central Gorakhnath shrine. Excavations revealed that these saddle stones sat on brick piers set in mud mortar, each $2 \mathrm{~m}$ deep. These were surrounded by a large squared $12 \times$ 12-m foundation wall, also $2 \mathrm{~m}$ deep and constructed from brick and mud mortar, with smaller double saddle stones placed on its surface to link to the timber superstructure (Fig. 9). We identified that the large saddle 


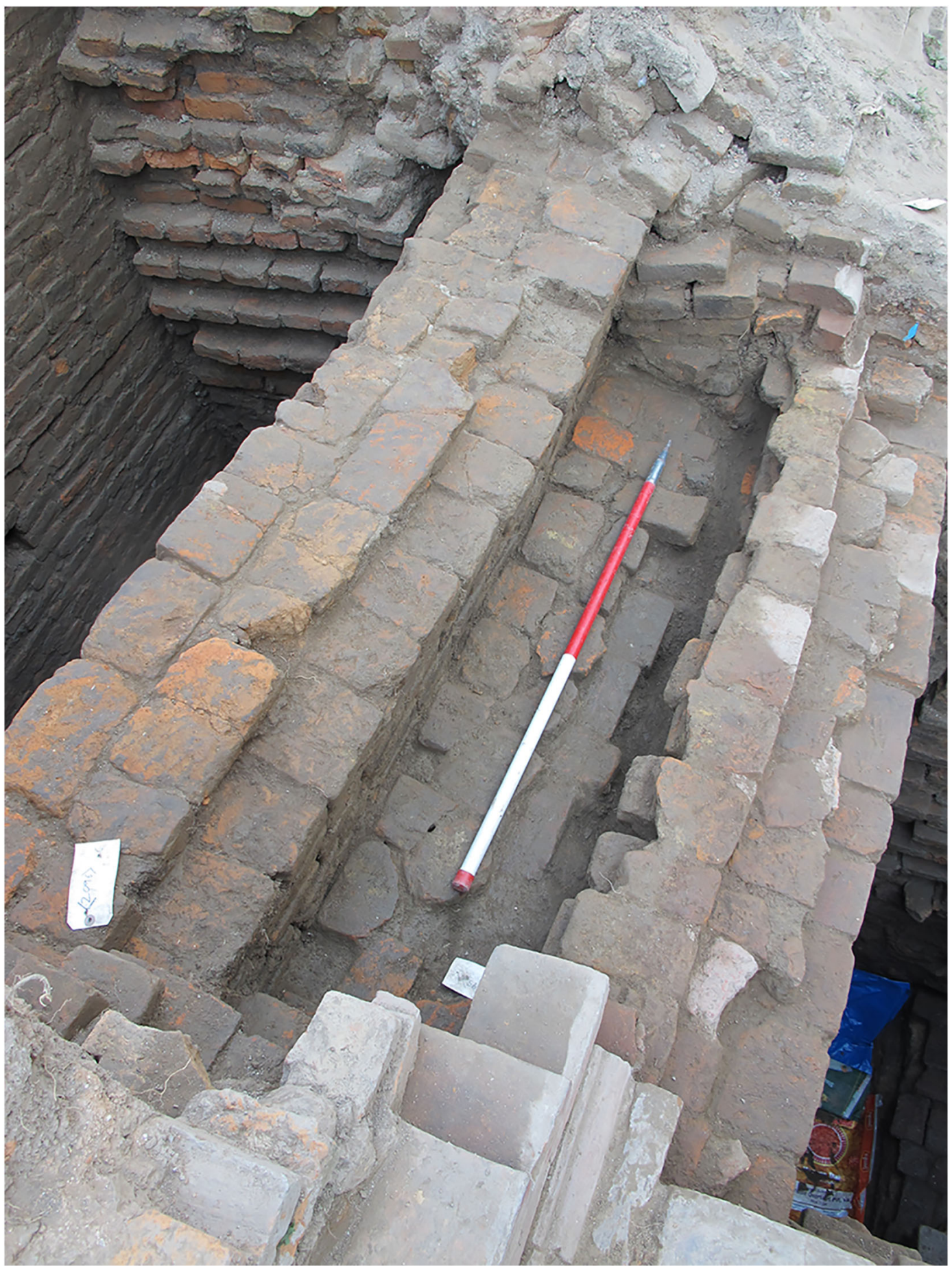

Fig. 7 Deformed and tilted wall, with later bracing, at Jaisidewal Temple (image: Keir Strickland)

stones had traces of copper sheeting on their surface, and these may have acted as a damp course between the wooden pillar and the saddle stone, a response to the annual monsoon (Coningham et al. 2016d).
Of the four central saddle stones, only three were visible after the removal of loose debris across the monument. Excavations revealed that the northeast saddle stone had been sealed below a tiled floor. It was 

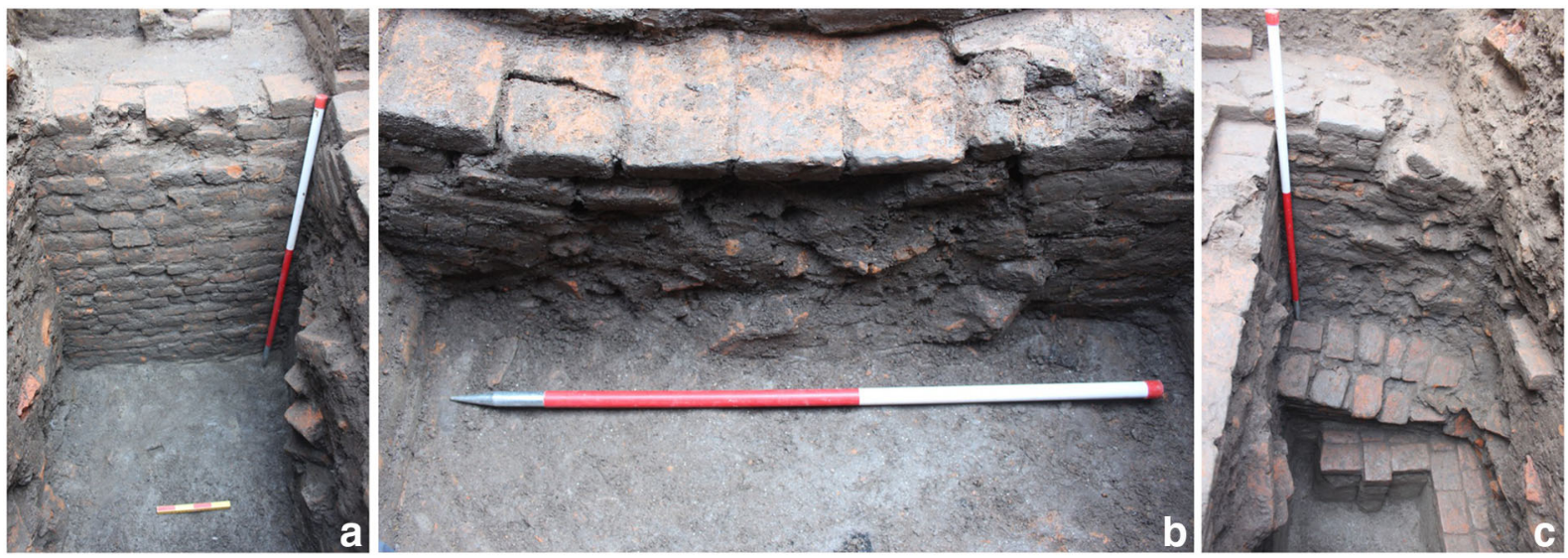

Fig. 8 Trench to the southwest of Jaisidewal Temple, with sequence of brick walls exhibiting shear crack and slight extrusion (a); tilting and collapse (b); crack and collapse of upper wall; and tilting of lower wall below (c)

identified that this had most likely occurred during conservation in the mid-twentieth century, where the rotten tenon of the large northeastern pillar was pushed into the socket below and then covered over by the tiled surface, rather than being replaced, which would have maintained the direct link between superstructure and foundations. This was likely to be a major contributing factor towards the Kasthamandap's collapse, as we found no major or catastrophic earthquake damage within the brick piers or foundations exposed during archaeological assessments, and no significant damage was reported for the monument in relation to the 1934 earthquake.

It would appear that the use of mud mortars within the foundations allowed for flexibility of the monument during seismic events. The only damage that could be linked to earthquakes was the identification of short vertical cracks located below a double saddle stone on the western length of the main foundation of the structure. Limited to the upper courses, it indicates stress of the load of the saddle stone and its interlinked superstructure, primarily induced by the pressure of vertical movement during a seismic event, causing the foundation below to be damaged (Coningham et al. 2018: 171; Fig. 10a). This also indicates that potential areas of stress and damage were minimised and localised, rather than causing catastrophic failures. It is likely that such a design with mud mortar brick masonry foundations linked to saddle stones and the superstructure above was designed to save the structure from further seismic stress, limiting damage to a few specific locations. Similar damage patterns and deformation of brickwork were also identified during excavations at the Gurujyu Sattal at Pashupati (Fig. 10b). Again, the load of the timbers placed within the saddle stones, which were bonded by mud mortar to the brick foundations, caused small concentrated areas of vertical cracks below.

Whilst it is not clear which seismic events these cracks may relate to, in the case of the Kasthamandap, scientific analysis through Optically Stimulated Luminescence dating has placed the construction of its original foundations to c. $700 \mathrm{CE}$. This is $400-500$ years earlier than its first mention within historical texts, illustrating that the Kasthamandap foundations were seismically adaptive and had survived numerous earthquakes, up to and including the 2015 Gorkha Earthquake (Coningham et al. 2016d; Coningham et al. 2018). Whilst we cannot be altogether certain whether the superstructure of the monument had been dismantled and rebuilt at points in antiquity until its collapse in 2015, the original foundations were resilient. A current programme of scientific dating analysis of timber within the Kasthamandap, and at other monuments within the Kathmandu Valley (Coningham et al. in 2019: 62), will provide further evidence of potential reuse of wooden architectural elements and whether different phases of the monument were constructed on top of these foundations at later dates, potentially in reaction to earthquakes.

We also identified that the monument may have had been designed with inbuilt cosmological protection, as cross-walls, scientifically dated to 200 years after the monument's original construction, running between the brick piers and foundations, forming a nine-celled mandala design (a representation of the universe in microcosm). These cross-walls may have also formed some aspect of seismic bracing for the foundations. It has further been identified that the infills deposited within 
the 'cells' formed by the cross-walls were purposefully prepared with soils and materials brought from outside. Preliminary geoarchaeological analysis suggesting that these deposits may have aided earthquake dampening for the monument's foundations, and the thoughtful compositions of soils placed within the monument's foundations may have taken on a symbolic significance, which has been recorded in textual sources (Coningham et al. 2019: 63). Further cosmological protection was identified with the recovery of gold foil discs with mandala designs within each of the sockets of the central saddle stones (Coningham et al. 2016d). Such deposits may have provided a 'life-breath' to a building and afforded its protection, as well as the prosperity and welfare to those performing the ceremony during the construction of a monument (Slaczka 2007: 84, 201).

Investigations at several other monuments within the Kathmandu Valley have also confirmed that foundations appear exceptionally resilient to earthquakes, with no seismic damage identified in the foundations of the Jagannath, Gopinath and the Trailokiya Mohan Temples in Hanuman Dhoka, as well as at the Char Narayan Temple in Patan (Coningham et al. 2016c) and Vatasala Temple in Bhaktapur (Coningham et al. 2016d). As detailed above, the disconnection caused by modern interventions between the resilient foundations and the superstructure above at the Kasthamandap was potentially a contributing factor towards collapse, rather than the structural integrity of traditional materials and design (Coningham et al. 2018: 171). This reflects observations on some modern structures, where earthquake damage to those built from reinforced concrete, as well as those using more traditional materials, has been linked to poor maintenance (Adhikary 2016: 535-536; Varum et al. 2017: 62) whereas those with well-maintained traditional earthquake-resistant features performed well (Adhikary 2016). Investigating causes of collapse, local soil conditions and the seismic adaptations and performance of the foundations and superstructures of historic monuments are therefore crucial within debates regarding pathways towards the rehabilitation of historic monuments after the 2015 Gorkha Earthquake.

\section{Discussion-resilience and the post-earthquake rehabilitation of Kathmandu's heritage}

Evidence from our recent multidisciplinary post-disaster investigations in the Kathmandu Valley has documented
EAEs within the archaeological record and has also identified how past societies responded to earthquakes and developed risk-reducing strategies to prepare for future seismic events. Whilst levelling damaged structures and reconfiguring space is one of the potential past responses identified, we have also uncovered adaptations inbuilt within monument design. Resilient and flexible foundations, constructed of brick within mud mortar, were in some cases combined with soils that may have been prepared to aid earthquake dampening. Potentially taking on a symbolic significance, cosmological designs for foundation layouts, as well as ritual deposits, may also have been devised to protect monuments and communities from future catastrophic events.

Whilst these adaptations and construction techniques appear to have created resilient structures, preliminary geotechnical results suggest that these traditional designs may not have been as successful when constructed in certain localities due to underlying natural soil conditions, such as at Jaisidewal. We will continue to assess and update our archaeological, geoarchaeological and architectural findings at monuments across the Kathmandu Valley in relation to new results emerging from continuing geotechnical and structural engineering investigations.

It is also noted, particularly from our research at the Kasthamandap, that traditional design and adaptations are only resilient if maintained and monitored. Indeed, it has been asserted that 'The historical architecture of Nepal is not only characterised by a remarkable continuity of theoretical principles of design, proportioning of form and consistent use of particular materials and décor but also by a tradition of conservation, involving reconstruction and renewal... This is of added significance as brick and timber, the materials of construction of the tiered temples, demanded regular replacement and maintenance not only as a matter of normal weathering but also in response to frequent destructions caused by earthquakes...' (Tiwari 2009: 27).

Recent rapid reconstruction programmes privileging modern materials are destroying subsurface heritage without recording, and also removing evidence of seismic adaptation and information regarding causes of collapse. Our investigations have shown the value and potential in undertaking multidisciplinary investigations to assess past seismic resilience and adaptations. The British Academy Global Challenges Research Fund sponsored project 'Reducing Disaster Risk to Life and Livelihoods by Evaluating the Seismic Safety of 


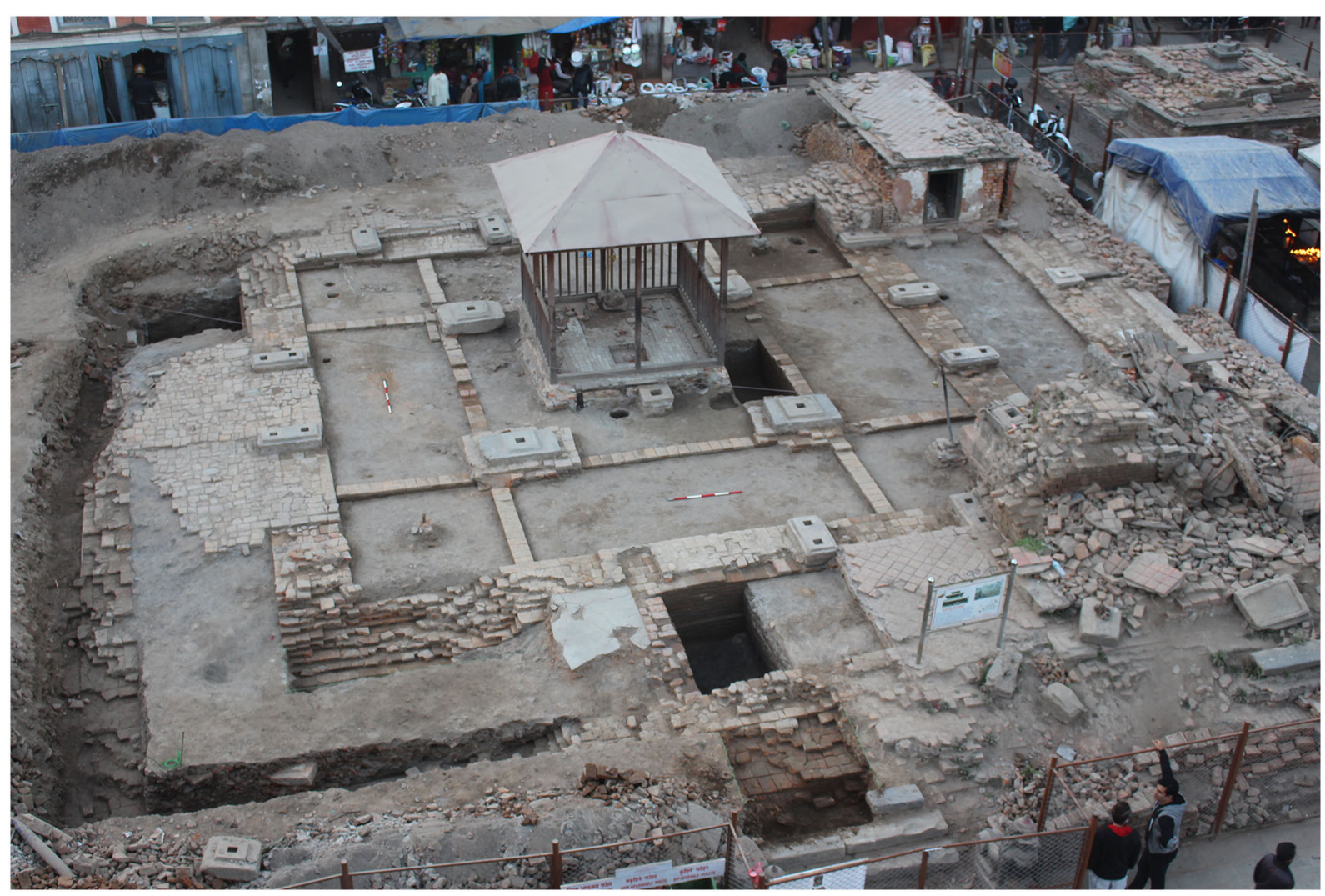

Fig. 9 Nine-celled mandala formed through brick-piers, foundation wall and cross-walls uncovered during archaeological assessments at the Kasthamandap

Kathmandu's Historic Urban Infrastructure', is the culmination of these multidisciplinary partnerships, and we continue to assess data from the integration of archaeology, geophysics, geoarchaeology and architectural studies with $3 \mathrm{D}$ visualisation, geotechnical and structural engineering, as well as community engagement to continue the development and disseminate co-produced methodologies to assess, evaluate and enhance the seismic safety of Kathmandu's historic urban infrastructure (Coningham et al. 2019). Such an approach has been seen as necessary in the field of archaeoseismology, where it has been identified that 'the scope and goals of archaeoseismological studies should still be broadened, benefiting from more intimate collaborations between earthquake geologists, historians, archaeologists and anthropologists in deciphering the precise role of earthquakes in the cultural history of a site. A better appreciation of the complex dynamics by which ancient cultures dealt with and responded to damaging earthquakes (e.g. anti-seismic measures) might shed light on the resilience of past societies and their relative capacity to withstand seismic shocks' and 'By highlighting how their ancestors coped with earthquakes, archaeoseismology could play a key role in fostering better earthquake preparedness in modern local communities that are equally threatened' (Sintubin 2011: 8). Such an approach is now being realised in Kathmandu and future results from the final analyses of geotechnical assessments, structural engineering, materials analysis and community interactions can be filtered into our current understandings from archaeology, geoarchaeology and traditional architecture. This combination of existing knowledge with multidisciplinary and interlinked research will enable the development of strategies for stakeholders with the responsibility of the reconstruction, rehabilitation and monitoring of Kathmandu's historic monuments, which is now being realised at the Kasthamandap (Coningham et al. 2019).

Such strategies are vital as societies in seismic regions are always living 'Between Two Earthquakes' (Feilden 1987: 11). In the recognition that similar post-disaster scenarios for heritage structures might be encountered 

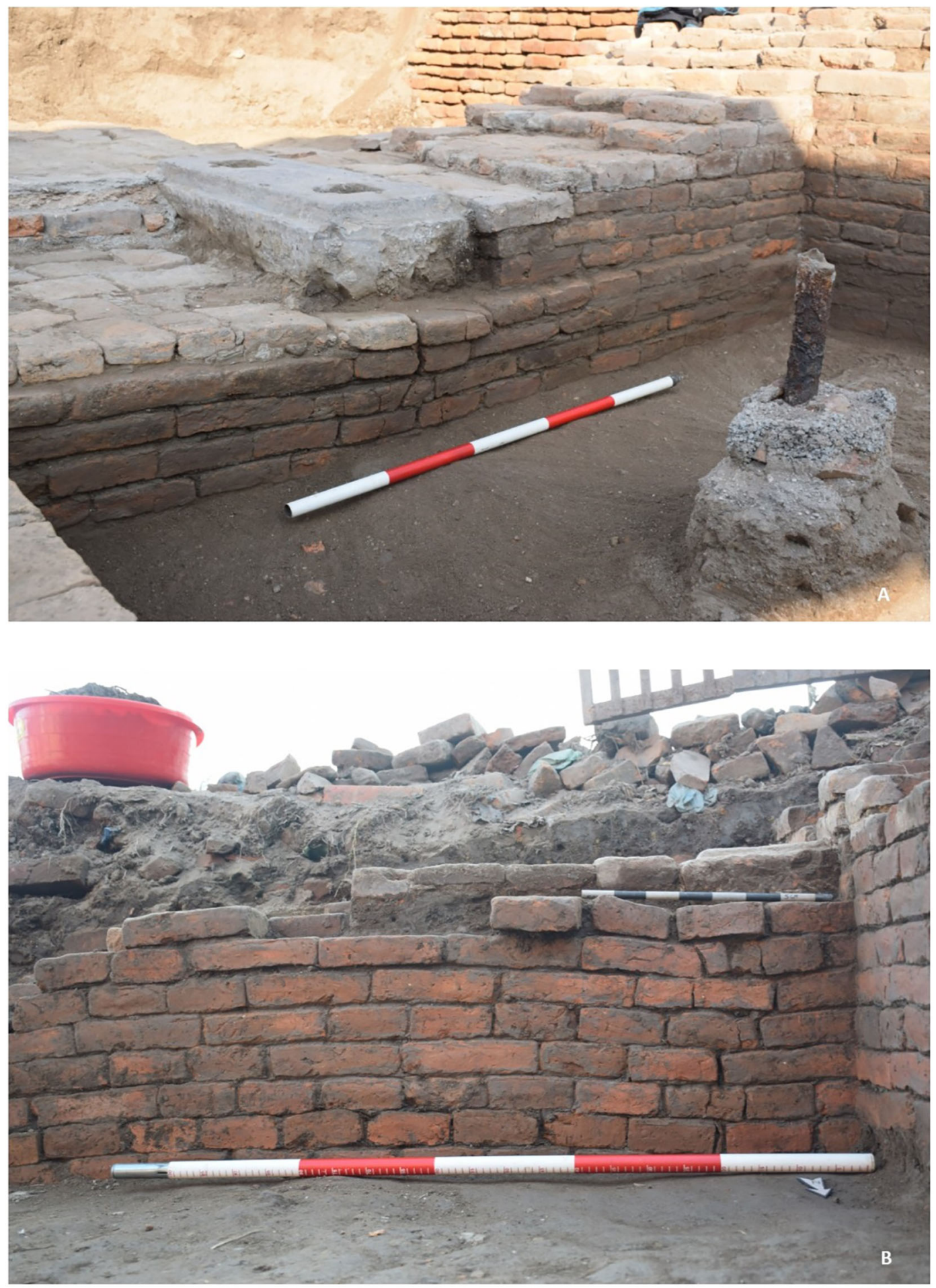

Fig. 10 Vertical cracks identified below a double saddle stone in the foundations of the Kasthamandap (a) and below a saddle stone in the foundations of the Gurujyu Sattal, Pashupati (b)

in the future, we began to co-develop archaeological approaches to assess and protect movable objects and debris, as well as structural elements, floor surfaces and foundations that survived the initial earthquake. In the 
immediate aftermath of emergency phase rescue operations, it was noted that debris from collapsed structures, including archaeological and architectural material, was mixed with modern rubble, was removed and dumped. Despite the painstaking efforts of Professor M.R. Aryal and the late Sukra Sagar Shrestha and their team, to salvage, document and attribute structural elements from collapsed structures within Hanuman Dhoka Durbar Square (Aryal 2017), many structural elements from across the Kathmandu Valley were lost or removed without their location being recorded. Beyond considerations of cultural value, the economic and environmental cost of dumping this material is huge, especially as firing bricks of a quality for heritage construction is estimated at $£ 1.31$ per brick (Coningham et al. 2018: 174). In response to this, a live training exercise conducted at Gurujyu Sattal at Pashupati, was co-designed with participants from the Armed Police Force, Nepal Police and Nepal Army, the Department of Archaeology (Government of Nepal) and the Pashupati Area Development Trust, to provide a method that could be applied to collapsed and damaged heritage (Coningham et al. 2018: 176-177; Coningham and Weise 2019).

It was identified that those first on the scene would need a quick and flexible approach that could be used at any collapsed monument, and could also be undertaken by key responders, with the potential that heritage professionals would not be able to attend the scene of every damaged heritage monument in the immediate aftermath of a disaster. The Gurujyu Sattal, a structure that had been deliberately demolished due to safety concerns after the 2015 Earthquake, offered the possibility of the replication of a post-earthquake scenario. Undertaken in a safe environment over a year after the 2015 Gorkha Earthquake, the participants worked together to systematically clear and record debris so that material recovered could be linked to a specific monument and broad location within a monument. Building on methods initially outlined by Feilden (1987: 41), a simple grid was placed across the site, with debris removed and then deposited in a replicated grid located close to the damaged monument. The creation of a replicated grid meant that debris was removed quickly onto intact foundations and floor surfaces, from where the trapped and injured are most likely to be, with the spatial location of recovered material recorded. This material can then be left until such a time that heritage professionals are available to process and analyse it, identifying artefacts and structural elements and materials that can be salvaged and reused (Coningham et al. 2018: 176-177).

Linked to this live-exercise, a post-disaster heritage response handbook was then co-designed alongside stakeholders including heritage practitioners, academics, key responders and community groups during the AHRC-GCRF sponsored workshop 'Heritage at Risk 2017', held in Kathmandu in September 2017. This handbook is now being developed into teaching materials as part of training programmes for these key responders and stakeholders. These methods were applied and tested in Bagan in Myanmar, for monuments affected by the August 2016 Earthquake, and transposed to monuments in Jaffna Fort, northern Sri Lanka, afflicted by human-made disasters (Davis et al. 2019; Coningham and Weise 2019). Furthermore, archaeological assessments, particularly GPR surveys and linked excavations, are being utilised to develop Archaeological Risk Maps to map, record and protect subsurface heritage, not only from unrecorded post-earthquake interventions, but also from more long-term and 'silent' disasters, such as unchecked development through rapid urbanisation (Coningham et al. 2018: 165). The bringing together of varied disciplines not only allows us to reconstruct the damage, adaptations, resilience and reactions of past societies towards earthquakes, but facilitates preparedness and protection of communities and heritage in the face of future seismic shocks.

Acknowledgements Fieldwork in Kathmandu would not have been possible without the support and dedication of the staff, officers and students from UNESCO Kathmandu, the Department of Archaeology (Government of Nepal), ICOMOS (Nepal), Pashupati Area Development Trust, Lumbini Buddhist University, Tribhuvan University, Durham University, the University of Stirling, the Maharaja Sayajirao University of Baroda, the University of La Trobe, University of Bradford, Newcastle University and the Institute for the Intellectual and Cultural History of Asia (Austrian Academy of Sciences). We are also appreciative of the first responders from the Nepal Police, Armed Police and Nepal Army for their participation and feedback on the live post-disaster training exercise co-developed at Pashupati. Further support from the Oriental Heritage Sites Protection Alliance facilitated the mobility of Officers from the Department of Archaeology (Government of Myanmar) and Central Cultural Fund (Government of Sri Lanka) to participate in the field programme in Kathmandu. We would also like to thank the Municipalities of Kathmandu, Patan and Bhaktapur, as well as the communities of the Kathmandu Valley, for their support and interest in our programme of post-disaster investigations. We are very thankful for the comments of the two anonymous reviewers who provided extremely useful feedback on the original submission of this paper. 
Funding information The post-disaster fieldwork undertaken in Kathmandu was funded by an Arts and Humanities Research Council Global Challenges Research Fund Grant (AH/P006256/ 1), a British Academy Global Challenges Research Fund Grant (CI170241) and two UNESCO funded missions (Contracts 4500283215 and 4500318125) awarded to Coningham as PI and a conservation award from the National Geographic Society (\#C333-16) awarded to Acharya as PI.

Open Access This article is distributed under the terms of the Creative Commons Attribution 4.0 International License (http:// creativecommons.org/licenses/by/4.0/), which permits unrestricted use, distribution, and reproduction in any medium, provided you give appropriate credit to the original author(s) and the source, provide a link to the Creative Commons license, and indicate if changes were made.

\section{References}

Adhikary N (2016) Vernacular architecture in post-earthquake Nepal. Int J Environ Stud 73(4):533-540

Amatya, S. (2007). Monument conservation in Nepal: my experience with the World Heritage Sites of the Kathmandu Valley. Vajra Publications, Kathmandu

Ambraseys NN (2006) Earthquakes and archaeology. J Archaeological Sci 33:1008-1016

Aryal, M.R. (2017). Inventory, Recording and storage. https://www.dur.ac.uk/cech/unescochair/workshops/ heritageatrisk/session2/. Accessed 02/04/2019.

Bajracharya, M., Gutschow, N. and Michaels, A. (2016). History of kings of Nepal. A Buddhist Chronicle. Himal Books, Kathmandu:

Bankoff G (2015) Design by Disaster. Seismic architecture and cultural adaptation to earthquakes. In: Krüger F, Bankoff G, Cannon T, Orlowski B, Schipper ELF (eds) Cultures and disasters. Understanding cultural framings in disaster risk reduction. Routledge, Abingdon, pp 53-71

Basukala, B, Gutschow, N. and Kayastha, K. (2014) Towers of stone: Sikhara Temples in Bhaktapur, Vatsala and Siddhilaksmi. Himal Books, Kathmandu

Behrendt KA (2009) The ancient reuse and recontextualization of Gandharan images: second to seventh centuries CE. South Asian Studies 25(1):11-27

Bernier, RM (1970) The temples of Nepal: an introductory survey. Voice of Kathmandu, Kathmandu

Bilham R (2004) Earthquakes in India and the Himalaya: tectonics, geodesy and history. Annals of Geophysics 47(2/3):839858

Bilham R, Bali BS (2014) A ninth century earthquake-induced landslide and flood in the Kashmir Valley, and earthquake damage to Kashmir's medieval temples. Bull Earthq Eng 12: 79-109

Bilham R, Lodi S (2010) The door knockers of Mansurah: strong shaking in a region of low perceived seismic risk, Sindh, Pakistan. In: Sintubin M, Stewart IS, Niemi TM, Altunel E (eds) Ancient earthquakes. The Geological Society of America Special Paper 471, Colorado, p 29.38
Callieri, P, Filigenzi, A and Stacul, G (1992) Bir-kot-ghwandai 1990-1992. A preliminary Report on the excavations of the Italian Archaeological Mission, IsMEO. Annali dell'Istituto Orientale di Napoli 52(4). Suppl. 73

Campbell A (2018) Account of the great earthquake of Nepal 1833. Ratna Putsak Bhandar, Kathmandu

Chaulagain H, Gautam D, Rodgrigues H (2017) Revisiting major historical earthquakes in Nepal: Overview of 1833, 1934, 1980, 1988, 2011, and 2015 seismic events. In: Gautam D, Rodrigues H (eds) Impacts and insights of the Gorkha earthquake. Elsevier, Amsterdam, pp 1-18

Coningham RAE, Weise K (2019) Ruins and debris: cultural heritage practice, resource management, and archaeology. In: Bicknell J, Judkins J, Korsmeyer C (eds) Philosophical perspectives on ruins, monuments, and memorials. Routledge, London, pp 275-290

Coningham, RAE and Young, RL (2015) The archaeology of South Asia: from the Indus to Asoka c.6500 BCE - 200 CE. Cambridge University Press, Cambridge

Coningham RAE, Acharya KP, Davis CE, Kunwar RB, Tremblay JC, Schmidt A, Simpson I, LaFortune-Bernard A (2016a) Post-disaster rescue archaeological investigations, evaluations and interpretations in the Kathmandu Valley World Heritage Property (Nepal): Observations and Recommendations from a UNESCO mission in 2015. Ancient Nepal 191-192:72-92

Coningham RAE, Acharya KP, Davis CE, Kunwar RB, Tremblay JC, Schmidt A, Simpson I (2016b) Preliminary results of post-disaster archaeological investigations at the Vatsala Temple and within Bhaktapur's Durbar Square, Kathmandu Valley UNESCO World Heritage Property (Nepal). Ancient Nepal 191-192:3-27

Coningham RAE, Acharya KP, Davis CE, Kunwar RB, Tremblay JC, Simpson IA, Schmidt A (2016c) Preliminary Results of post-disaster archaeological investigations at the Char Narayan Temple and within Patan's Durbar Square, Kathmandu Valley UNESCO World Heritage Property (Nepal). Ancient Nepal 191-192:52-71

Coningham RAE, Acharya KP, Davis CE, Kunwar RB, Simpson IA, Schmidt A, Tremblay JC (2016d) Preliminary Results of Post-Disaster Archaeological Investigations at the Kasthamandap and within Hanuman Dhoka, Kathmandu Valley UNESCO World Heritage Property (Nepal). Ancient Nepal 191-192:28-51

Coningham RAE, Acharya KP, Davis CE, Weise K, Kunwar RB, Simpson IA (2018) Look Down, Not Up: Protecting the postdisaster subsurface heritage of the Kathmandu Valley's UNESCO World Heritage Site. In: Bracken LA, Ruszczyk $\mathrm{H}$, Robinson $\mathrm{T}$ (eds) Evolving narratives of hazard and risk the Gorkha earthquake, Nepal, 2015. Palgrave Macmillan, Cham, pp 159-181

Coningham RAE, Acharya KP, Barclay CP, Barclay R, Davis CE, Graham C, Hughes PN, Joshi A, Kelly L, Khanal S, Kilic A, Kinnaird T, Kunwar RB, Kumar A, Maskey PN, LafortuneBernard A, Lewer N, McCaughie D, Mirnig N, Roberts A, Sarhosis V, Schmidt A, Simpson IA, Sparrow T, Toll DG, Tully B, Weise K, Wilkinson S, Wilson A (2019) Reducing disaster risk to life and livelihoods by evaluating the seismic safety of Kathmandu's historic urban infrastructure: enabling an interdisciplinary pilot. J Br Acad 7(S2):45-82 
Davis CE, Coningham RAE, Gunawardhana P, Pushparatnam P, Schmidt A, Manuel MJ (2019) The antiquity of Jaffna Fort: new evidence from post-disaster archaeological investigations in northern Sri Lanka. Antiquity 93(368):e13

Feilden B (1987) Between two earthquakes: cultural property in seismic zones. ICCROM, Rome

Forlin P, Gerrard CM (2017) The archaeology of earthquakes: the application of adaptive cycles to seismically-affected communities in late medieval Europe. Quat Int 446:95-108

Galadini F, Hinzen KG, Stiros S (2006) Archaeoseismology: methodological issues and procedure. J Seismol 10:395414. https://doi.org/10.1007/s10950-006-9027-x

Gautam D, Pradhananga S, Kunwar RB, Sharma MK (2015) Preliminary report of monuments affected by earthquake April 25 2015. Department of Archaeology, Kathmandu

Giner-Robles, JL, Rodríguez-Pascua, MA, Pérez-López, R, Silva, PG, Bardají, T, Grützner, C, Reicherter, K (2009) Structural analysis of earthquake archaeological effects (EAE): Baelo Claudia Examples (Cádiz, South of Spain). 1st INQUAIGCP 567 International Workshop on Earthquake Archaeology and Palaeoseismology. Volume 2. Instituto Geológico y Minero, Madrid

Guidoboni E, Ebel JE (2009) Earthquakes and Tsunamis in the Past. A Guide to Techniques in Historical Seismology. Cambridge University Press.

Gutschow N (1997) The Nepalese Caitya: 1500 years of Buddhist votive architecture in the Kathmandu Valley, Stuttgart

Gutschow N (2011) Architecture of the Newars: a history of building typologies and details in Nepal. Serindia Publications, Chicago

Gutschow N, Hagmuller G (1991) The reconstruction of the eightcornered pavilion (Cyasilin Mandap) on Darbar Square in Bhaktapur-Nepal. Ancient Nepal 123-125:1-9

http://whc.unesco.org/en/list/121/ Accessed 23/04/2019. (n.d.)

Hutt M (ed) (1994) Nepal: a guide to the art and architecture of the Kathmandu Valley. Kiscadale Publications, Stirling

Joshi M, Thakur VC (2016) Signatures of 1905 Kangra and 1555 Kashmir Earthquakes in medieval period temples of Chamba Region, Northwest Himalaya. Seismol Res Lett 86(5):11501160

Kázmér M (2019) Living with earthquakes along the Silk Road. In: Yang LE, Bork H-R, Fang X, Mischke S (eds) Socioenvironmental dynamics along the historical Silk Road. Springer, Cham, pp 135-176

Kázmér M, Major B, Hariyadi A, Pramumijoyo S, Haryana YD (2010) Living with earthquakes - development and usage of earthquake-resistant construction methods in European and Asian Antiquity. Geophys Res Abstr 12:EGU2010EG14244

Khanal MP, Riccardi T (2007) Archaeological excavations in the Kathmandu Valley. In: A Report on the 1984-85 and 1988-89 Seasons at Dumakhal. Harvard, Harvard Oriental Series

Korn W (2007) The traditional architecture of the Kathmandu Valley, 2nd edn. Ratna Pustak Bhandar, Kathmandu

Korn W (2014) The traditional Newar architecture of the Kathmandu Valley: the Shikaras. Ratna Pustak Bhandar, Kathmandu

Kovach RL, Grijalva K, Nur A (2010) Earthquakes and civilizations of the Indus Valley: a challenge for archaeoseismology. In: Sintubin M, Stewart IS, Nieme TM, Altunel E (eds)
Ancient Earthquakes. The Geological Society of America, Special Paper 471, Colorado, pp 119-128

Langenbach R (2007) From "Opus Craticium" to the "Chicago Frame": earthquake-resistant traditional construction. Int J Archit Herit 1:29-59

Marshall JH (1951) Taxila, vol 1. Cambridge University Press, Cambridge

Olivieri LM (2011) The last phases at Barikot: urban cults and preliminary chronology: Data from the 2012 excavation campaign in Swat. J Inn Asian Art Archaeol 6:7-40

Olivieri LM (2015) Urban Defences at Bīr-koț-ghwaṇụai, Swat (Pakistan). New data from the 2014 Excavation Campaign. Ancient Civilizations from Scythia to Siberia 21:183-199

PDNA (2015) Post disaster needs assessment: cultural heritage (June 2015). UNESCO, Kathmandu

Petech, L (1984) Medieval history of Nepal (c. 750-1482). IsMEO, Roma

Prushca K (2015) Kathmandu Valley, Volumes 1 and 2, 2nd edn. Vajra Books, Kathmandu

Rajendran CP, Rajendran K (2003) Studying earthquake recurrence in the Kachchh Region, India. Trans Am Geophys Union 84(48):529-536

Rajendran CP, Rajendran K, Thakkar M, Goyal B (2008) Assessing the previous activity at the source zone of the 2001 Bhuj earthquake based on the near-source and distant paleoseismological indicators. J Geophys Res 113:1-17

Rajendran CP, Rajendran K, Sanwal J, Sandiford M (2013) Archaeological and historical database on the medieval earthquakes of the Central Himalaya: ambiguities and inferences. Seismol Res Lett 84(6):1098-1108

Rana, BSJB (2013 1934) (trans. From the second edition by Kesar Lall). The great earthquake in Nepal (1934 A.D.). Dongol Printers, Nepal

Regmi DR (1983) Inscriptions of Ancient Nepal. Abhinav Publications, New Delhi

Rodríguez-Pascua MA, Pérez-López R, Giner-Robles JL, Silva PG, Garduño-Monroy VH, Reicherter K (2011) A comprehensive classification of Earthquake Archaeological Effects (EAE) in archaeoseismology: application to ancient remains of Roman and Mesoamerican Cultures. Quat Int 242:20-30

Rupakhety R (2017) Seismotectonic and engineering seismological aspects of the Mw 7.8 Gorkha, Nepal, Earthquake. In: Gautam D, Rodrigues H (eds) Impacts and Insights of the Gorkha Earthquake. Elsevier, Amsterdam, pp 19-46

Silva PG, Sintubin M, Reicherter K (2011) New advances in studies of earthquake archaeology and palaeoseismology. Quat Int 424:1-3

Sintubin M (2011) Archaeoseismology: past, present and future. Quat Int 242:4-10

Slaczka AA (2007) Temple consecration rituals in Ancient India: text and archaeology. Brill, Leiden

Slusser MS, Vajracarya G (1974) Two medieval Nepalese buildings: an architectural and cultural study. Artibus Asiae 36(3):169-218

Stiros, SC and Jones, RE (eds) (1996) Archaeoseismology. Fitch Laboratory Occasional Paper 7, Institute of Geology and Mineral Exploration and The British School at Athens, Athens

Strickland, KM 20172016 Archaeological investigations of a collapsed square tiered temple, post- Gorkha Earthquake: Jaisideval, Kathmandu, Nepal. Technical Report submitted to the Department of Archaeology, Government of Nepal, Kathmandu 
Thapa RJ (1968) Kasthamandapa. Ancient Nepal 3:33-43

Tiwari SR (2009) Temples of the Nepal Valley. Himal Books, Kathmandu

UNESCO (2015) Revisiting Kathmandu: safeguarding living urban heritage. International Symposium, Kathmandu Valley. 25-29 November 2013. UNESCO, Kathmandu

Vajracharya D, Malla KP (1985) The Gopālarājavaṃśāvalī: a facsimile edition; with an introduction, a transcription, Nepali and English translations, a glossary and indices. Steiner, Stuttgart

Varum H, Dumaru R, Furtado A, Barbosa AR, Gautam D, Rodrigues H (2017) Seismic performance of buildings in Nepal after the Gorkha earthquake. In: Gautam D,
Rodrigues H (eds) Impacts and insights of the Gorkha Earthquake. Elsevier, Amsterdam, pp 47-64

Verardi G (1992) Excavations at Harigaon Kathmandu. IsMEO, Rome Weise K, Gautam D, Rodrigues H (2017) Response and rehabilitation of historic monuments after the Gorkha earthquake. In: Gautam D, Rodrigues H (eds) Impacts and insights of the Gorkha Earthquake. Elsevier, Amsterdam, pp 65-94

Publisher's note Springer Nature remains neutral with regard to jurisdictional claims in published maps and institutional affiliations. 